\title{
Prawo pacjenta do świadczeń zdrowotnych z zakresu lecznictwa uzdrowiskowego
}

\section{Wprowadzenie}

Lecznictwo uzdrowiskowe stanowi kontynuację leczenia szpitalnego lub ambulatoryjnego. Ta zorganizowana działalność polegająca na udzielaniu świadczeń zdrowotnych prowadzona jest bowiem jedynie na wydzielonym obszarze gminy - w uzdrowisku i specjalnie do tego przystosowanych podmiotach leczniczych - zakładach lecznictwa uzdrowiskowego. W trakcie korzystania $z$ tej kuracji pacjenci są poddawani kompleksowym programom leczniczym. Dzięki nim umożliwia się leczenie chorób przewlekłych, które w obecnej dobie pochłaniają duże koszty na leczenie naprawcze, rehabilitację oraz opiekę socjalno-medyczną.

Celem artykułu jest analiza i ocena regulacji prawnych jednego z ustawowych katalogów praw pacjenta, jakim jest prawo do świadczeń zdrowotnych z zakresu lecznictwa uzdrowiskowego. Podjęte zagadnienie ze względu na swoją złożoność i wielość aktów normatywnych obowiązujących w tym zakresie pozwala na zbadanie ich wpływu na obecny status pacjenta zakładu lecznictwa uzdrowiskowego, określenie miejsca lecznictwa uzdrowiskowego w systemie ochrony zdrowia, zasad dostępności do świadczeń uzdrowiskowych, kwestii finansowania tej formy leczenia oraz barier i ograniczeń decydujących o dzisiejszym kształcie zagadnień uzdrowiskowych.

* Paulina Jachimowicz-Jankowska, mgr, Uniwersytet im. Adama Mickiewicza w Poznaniu, e-mail: janpkows@amu.edu.pl, https://orcid.org/0000-0002-6061-1220. 
Nie ulega wątpliwości, że pacjenci stanowią szczególną kategorię osób (fizycznych). Nie powinno więc również dziwić wzmożone zainteresowanie prawami pacjentów, które powodowane jest gwałtownym postępem medycyny ${ }^{1}$ i pojawieniem się nowych technologii medycznych ${ }^{2}$, a także upowszechnieniem dostępu do świadczeń zdrowotnych.

W różny sposób rysuje się jednak status prawny pacjenta kierowanego na leczenie uzdrowiskowe albo rehabilitację uzdrowiskowa, a co za tym idzie - korzystającego z obejmujących te obszary gwarantowanych świadczeń zdrowotnych. Według dostępnych danych z roku na rok wzrasta zainteresowanie pacjentów tą formą leczenia ${ }^{3}$. Pomimo to stosowanie przepisów w tym zakresie budzi wiele wątpliwości interpretacyjnych, a dostęp pacjentów do świadczeń uzdrowiskowych w ramach Narodowego Funduszu Zdrowia (NFZ) jest nadal znacznie limitowany. Bariery w tym zakresie kreuje nieraz samo życie, co wiąże się $\mathrm{z}$ zaistnieniem zagrożenia dla bezpieczeństwa zdrowotnego społeczeństwa.

Zagadnienie praw pacjenta w powiązaniu z lecznictwem uzdrowiskowym tworzy szeroki obszar badawczy. Wspólnym mianownikiem bezsprzecznie jest zdrowie ludzkie będące najwyższą wartością dla każdego człowieka, z której wynikają wszystkie inne przysługujące mu prawa i wolności, w związku z czym podlega ono szczególnej ochronie ${ }^{4}$. Obywatelom przysługują zatem konstytucyjne podmiotowe prawa do należytej „ochrony zdrowia”, a władze publiczne mają obowiązek zorganizowania systemu "ochrony zdrowia" ${ }^{\text {. }}$.

W obowiązującym w Polsce porządku prawnym ustawodawca używa terminu „ochrona zdrowia” zarówno w Konstytucji Rzeczypospolitej ${ }^{6}$, jak i aktach prawa międzynarodowego ratyfikowanych przez Polskę oraz

${ }^{1} \mathrm{~J}$. Bujny, Prawa pacjenta. Między autonomia a paternalizmem, Warszawa 2007, s. 3.

2 Por. G. Hołub, Pacjent jako osoba, w: Bioetyka w zawodzie lekarza, pod red. W. Chańskiej, J. Hartmana, Warszawa 2010, s. 39; M. Sygit, Zdrowie publiczne, Warszawa 2010, s. $464-485$.

${ }^{3}$ Działalność lecznicza zakładów lecznictwa uzdrowiskowego i stacjonarnych zakładów rehabilitacji leczniczej w 2018 r. Informacje sygnalne z dnia 14 VI 2019 r., dalej GUS $z 2018$ r. - notka, s. 1-5.

${ }^{4}$ R. Michalska-Badziak, Ochrona zdrowia. Zagadnienia ogólne, w: Prawo administracyjne materialne, pod red. Z. Duniewskiej, B. Jaworskiej-Dębskiej, M. Stahl, Warszawa 2014, s. $227-228$.

${ }^{5}$ M. Dercz, H. Izdebski, T. Rek, Prawo publiczne ochrony zdrowia, pod red. M. Dercza, Warszawa 2013, s. $41 \mathrm{n}$.

${ }^{6}$ Konstytucja Rzeczypospolitej Polskiej z dnia 2 IV 1997 r. (Dz.U. Nr 78, poz. 483 ze zm.), dalej „Konstytucja RP”. 
w licznych ustawach ${ }^{7}$. Żaden jednak akt prawny wpisany w obecnie obowiązujący system legislacyjny nie przedstawia uniwersalnej definicji tego pojęcia, mimo ewidentnej potrzeby praktycznej. Niemniej w ujęciu doktryny pojęcie "ochrona zdrowia" opiera się na kilku aspektach, a szczególne znaczenie mają: promocja zdrowia i opieka zdrowotna ${ }^{8}$. Co więcej, można przyjąć, że ochrona zdrowia to suma wiedzy o obowiązujących standardach i zasadach zapobiegania oraz strategia postępowania diagnostyczno-terapeutycznego w zwalczaniu chorób trapiących ludzkość. Podstawowym zaś celem całego systemu ochrony zdrowia jest zapewnienie bezpieczeństwa zdrowotnego ludzi. Dokonuje się to poprzez zaspokajanie indywidualnych potrzeb medycznych, a także poprzez działania mające na celu zapewnienie odpowiednich warunków życia, pracy i innych aspektów życia, które zapobiegają lub zmniejszają ryzyko utraty zdrowia9 .

Najważniejszym źródłem prawa do ochrony zdrowia są przepisy art. 68 Konstytucji RP. W nich została wskazana fundamentalna dla funkcjonowania całego systemu ochrony zdrowia zasada, zgodnie z którą każdemu przysługuje prawo do ochrony zdrowia i równy dostęp do świadczeń opieki zdrowotnej finansowanej ze środków publicznych. Postanowienia konstytucyjne korespondują z przepisami odrębnymi dotyczącymi pacjenta i lecznictwa uzdrowiskowego i w układzie chronologicznym są to następujące regulacje: Ustawa z dnia 5 grudnia $1996 \mathrm{r}$. o zawodach lekarza i lekarza dentysty ${ }^{10}$, Ustawa z dnia 27 sierpnia 2004 r. o świadczeniach opieki zdrowotnej finansowanych ze środków publicznych ${ }^{11}$, Ustawa z dnia 28 lipca 2005 r. o lecznictwie uzdrowiskowym, uzdrowiskach i obszarach ochrony uzdrowiskowej oraz o gminach uzdrowiskowych ${ }^{12}$, Ustawa $z$ dnia 6 listopada 2008 r. o prawach pacjenta i Rzeczniku Praw Pacjenta ${ }^{13}$ oraz Ustawa z dnia 11 kwietnia 2011 r. o działalności leczniczej ${ }^{14}$.

${ }^{7}$ J. Nosko, Promocja zdrowia $i$ ochrona zdrowia jako zadania własne samorzadu terytorialnego, cz. 2, "Zdrowie Publiczne” 2000, nr 5, s. 187 i n. Wybór regulacji w zakresie ochrony zdrowia na poziomach: międzynarodowym, regionalnym i krajowym prezentuje K. Wojtczak, Kompetencje i zadania jednostek samorządu terytorialnego w zakresie bezpieczeństwa zdrowia ludzi, "Studia Prawa Publicznego" 2018, nr 3(23), s. 10-13.

${ }^{8} \mathrm{~J}$. Nosko, Promocja zdrowia $i$ ochrona zdrowia jako zadania własne samorzadu terytorialnego, cz. 1, "Zdrowie Publiczne” 2000, nr 4, s. 149.

${ }^{9}$ R. Michalska-Badziak, op. cit., s. 227.

10 Tekst jedn. Dz.U. 2019, poz. 537 ze zm., dalej „u.z.l.”.

11 Tekst jedn. Dz.U. 2019, poz. 1373 ze zm., dalej „u.ś.o.z.”.

12 Tekst jedn. Dz.U. 2017, poz. 1056 ze zm., dalej "ustawa uzdrowiskowa” lub „ustawa”.

${ }^{13}$ Tekst jedn. Dz.U. 2019, poz. 1127 ze zm., dalej „ustawa o prawach pacjenta” lub „u.p.p.”.

14 Tekst jedn. Dz.U. 2020, poz. 295 ze zm., dalej „u.d.1.”. 


\section{Pojęcie i rys historyczny praw pacjenta oraz definicja pacjenta}

\subsection{Pojęcie praw pacjenta}

Pojęcie praw pacjenta stosowane $w$ języku prawnym i prawniczym służy realizacji zamierzeń akceptowanych w polityce zdrowotnej kraju ${ }^{15}$. Rozwój tych praw wiąże się ze wzrostem liczby regulacji prawnych, szeroko rozumianej relacji zachodzącej między pacjentem a całą złożoną infrastrukturą instytucjonalną i różnymi podmiotami udzielającymi świadczeń zdrowotnych. W relacji tej zaciera się różnica między sferą publiczną i prywatną oraz tradycyjny stosunek lekarz - pacjent, gdyż obecnie udzielanie świadczeń opieki zdrowotnej następuje przy udziale podmiotów leczniczych i wielu grup zawodów medycznych ${ }^{16}$.

W polskiej literaturze przedmiotu wskazuje się, że o prawach pacjenta można mówić w relacji (1) pacjent - władza publiczna (są to organy władzy właściwe w zakresie ochrony zdrowia ${ }^{17}$, do których należą: Minister Zdrowia ${ }^{18}$, wojewoda ${ }^{19}$ i organy jednostek samorządu terytorialnego ${ }^{20}$ ) oraz (2) pacjent - konkretny podmiot uprawniony do udzielania świadczeń zdrowotnych ${ }^{21}$. W kontekście pierwszej relacji mowa jest o pacjencie-obywatelu, względem którego władza publiczna

${ }^{15}$ D. Karkowska, Ustawa o prawach pacjenta i Rzeczniku Praw Pacjenta. Komentarz, Warszawa 2012, s. 17.

${ }^{16}$ Szerzej: D. Karkowska, Prawa pacjenta, Warszawa 2009, s. 194, dalej Prawa pacjenta. Potwierdza to art. 2 u.p.p.: podmiotami właściwymi do przestrzegania praw pacjenta są organy władzy publicznej właściwe w zakresie ochrony zdrowia, Narodowy Fundusz Zdrowia, podmioty udzielające świadczeń zdrowotnych, osoby wykonujące zawód medyczny i inne osoby uczestniczące w udzielaniu świadczeń zdrowotnych.

17 Por. wyrok Trybunału Konstytucyjnego z 7 I 2004 r., sygn. K 14/03, sentencja wyroku ogłoszona 15 I 2004 r. (Dz.U. Nr 5, poz. 37).

18 Ustawa z dnia 4 IX 1997 r. o działach administracji rządowej (tekst jedn. Dz.U. 2019, poz. 1148 ze zm.). Por. art. 5 pkt 28 w zw. z art. 33 tego aktu, zgodnie z którymi Minister Zdrowia kieruje działem administracji rządowej - „zdrowie” - obejmującym sprawy m.in. lecznictwa uzdrowiskowego.

${ }^{19}$ Ustawa z dnia 23 I 2009 r. o wojewodzie i administracji rządowej w województwie (tekst jedn. Dz.U. 2019, poz. 1464 ze zm.).

${ }^{20}$ Zob. w tym zakresie „ustawy samorządowe”: Ustawa z dnia 8 III 1990 r. o samorządzie gminnym (tekst jedn. Dz.U. 2019, poz. 506 ze zm.), Ustawa z dnia 5 VI 1998 r. o samorządzie powiatowym (tekst jedn. Dz.U. 2019, poz. 511 ze zm.), Ustawa z dnia 5 VI 1998 r. o samorządzie województwa (tekst jedn. Dz.U. 2019, poz. 512 ze zm.).

${ }^{21}$ Na przykład M. Dercz, T. Rek, Ustawa o zakładach opieki zdrowotnej. Komentarz, Warszawa 2007, s. 121 i n. 
jest zobowiązana do podjęcia określonych działań w celu realizacji zobowiązań pozytywnych oraz negatywnych. Chodzi tu o urzeczywistnienie $\mathrm{w}$ ramach funkcjonowania państwa zarówno praw o charakterze społecznym, jak i obywatelskim, a prawa pacjenta mają charakter norm abstrakcyjnych i ogólnych. W kontekście drugiej relacji „prawa pacjenta mają charakter norm konkretnych, które z jednej strony wskazują na obowiązki podmiotów udzielających świadczeń zdrowotnych [...], z drugiej zaś na prawa pacjenta związane z ochroną ich dóbr osobistych"22. $^{\prime 2}$.

Gwarancje dotyczące tego typu praw wynikają z obowiązujących aktów prawnych i pokazują relacje między świadczeniodawcami a pacjentami $^{23}$. Obecnie ustawodawca polski uregulował w jednym akcie prawnym (u.p.p.) prawa pacjenta o charakterze podstawowym ${ }^{24}$. Celem praw pacjenta ${ }^{25}$ zasadniczo jest ochrona autonomii (wolności) pacjenta przed ingerencją ze strony innych podmiotów, ale i prawo domagania się realizacji tych praw. Są to normy, które określają sposoby kontroli przestrzegania oraz dochodzenia (egzekwowania) praw pacjenta w stosunku do władz, podmiotów (podmiotu leczniczego, lekarza, personelu medycznego) i instytucji, które owych praw nie respektują ${ }^{26}$.

\subsection{Geneza praw pacjenta}

Prawa pacjenta mają długą tradycję $e^{27}$. Wskazując rys historycznych tego typu praw, warto wspomnieć, że ówczesny ustawodawca początkowo

${ }^{22}$ Ibidem.

${ }^{23}$ Por. D. Karkowska, Prawa pacjenta, s. 20 i n.

${ }^{24}$ Zob. J. Bujny, op. cit., s. 237-326. Autor szeroko omawia prawa pacjenta w szczególnych sytuacjach prawnych - poza sferą ustawy o prawach pacjenta - takich jak np.: pacjenci szpitali psychiatrycznych, pacjenci chorzy na choroby zakaźne, dawcy i biorcy narządów, tkanek i komórek, osoby uzależnione, poddające się transplantacji czy eksperymentom medycznym.

${ }^{25}$ Zob. np. W. Jakimowicz, Publiczne prawa podmiotowe, Kraków 2002, s. 218, 221; J. Jończyk, Strony i stosunki powszechne ubezpieczenia zdrowotnego, "Prawo i Medycyna" 2005, nr 1, s. 36; J. Bujny, op. cit., s. 26 i n.

${ }^{26}$ Por. np. M. Dercz, T. Rek, Prawa dziecka jako pacjenta, Warszawa 2003, s. 7.

${ }^{27} \mathrm{~W}$ układzie chronologicznym istotne znaczenie w tym zakresie odgrywały m.in.: Ustawa z dnia 19 V 1920 r. o obowiązkowym ubezpieczeniu na wypadek choroby (Dz.U. Nr 44, poz. 272), Rozporządzenie z dnia 22 III 1928 r. o zakładach leczniczych (Dz.U. Nr 38, poz. 382), Ustawa z dnia 28 III 1933 r. o ubezpieczeniu społecznym (Dz.U. Nr 51, poz. 396), Ustawa z dnia 28 X 1948 r. o zakładach społecznych służby zdrowia i planowej gospodarce w służbie zdrowia (Dz.U. Nr 55, poz. 434 ze zm.), 
nie posługiwał się pojęciem „pacjent”, ale „chory”. Przy czym: (1) w literaturze przyjmuje się, iż "pojęcie «pacjent» jest pojęciem o zakresie szerszym niż pojęcie "chory»" $28,(2)$ jednak żadne z tych dwóch pojęć, tj. "pacjent" i "chory”, nie zostało wówczas ustawowo zdefiniowane.

Pomimo że początek kształtowania się praw chorego (pacjenta) przypada na okres odzyskania niepodległości Polski ${ }^{29}$, to przez wiele lat obowiązujący wówczas system opieki zdrowotnej ukazywał pacjenta w relacjach z osobami wykonującymi zawody medyczne jako „bierny podmiot ${ }^{\prime \prime 30}$. Taki stan potwierdzały także przeprowadzone w tym zakresie badania socjologiczne $\mathrm{z}$ końca lat osiemdziesiątych $\mathrm{XX}$ w. ${ }^{31}$

Istotne zmiany polegające na zwiększeniu udziału obywateli w różnych dziedzinach funkcjonowania społeczeństwa, w tym w sferze polityki zdrowotnej ${ }^{32}$, były wynikiem procesów transformacji społeczno-gospodarczej zapoczątkowanej po 1989 r. Sprzyjały one bowiem stopniowemu wprowadzaniu (a także kolejno popularyzacji) praw pacjenta do uchwalanych w tym okresie ustaw ${ }^{33}$ oraz stanowiły pewien wyznacznik postępowania wszystkich osób (lekarze, pielęgniarki i położne) i podmiotów (zakłady opieki zdrowotnej) działających w obrębie ochrony zdrowia. Warto zatem wskazać w układzie chronologicznym kilka regulacji odgrywających ważną rolę i tym samym mających istotny wpływ na proces kształtowania się praw pacjenta w polskim porządku prawnym.

Pierwszą z nich jest Ustawa z dnia 17 maja 1989 r. o izbach lekarskich $^{34}$, na której mocy reaktywowano samorząd lekarski i wydano nadzwyczajną uchwałę II Krajowego Zjazdu Lekarzy z dnia 14 grudnia

Rozporządzenie Ministra Zdrowia i Opieki Społecznej z dnia 18 VIII 1962 r. w sprawie bezpłatności niektórych świadczeń zakładów społecznych służby zdrowia (Dz.U. Nr 55, poz. 277 ze zm.).

${ }^{28}$ J. Bujny, op. cit., s. 9. Termin "chory” w ujęciu słownikowym oznacza dotknięty choroba, chorujący, cierpiący (Stownikjęzyka polskiego, t. 1, Warszawa 1978, s. 274).

${ }^{29}$ Zob. J. Fijałek, J. Indulski, Opieka zdrowotna w Łodzi do roku 1845. Studium organizacyjno-prawne, Łódź 1990, s. 298-300.

${ }^{30}$ J. Bujny, op. cit., s. 3; D. Karkowska, Prawa Pacjenta, Warszawa 2004, s. 388-389, dalej Prawa Pacjenta.

${ }^{31} \mathrm{~J}$. Halik, Możlizwości instytucjonalnej ochrony praw pacjenta w Polsce, w: Prawo do opieki zdrowotnej w systemie gospodarki rynkowej, pod red. M. Safjana, Warszawa 1993, s. 81-82.

${ }^{32}$ C. Włodarczyk, Reforma opieki zdrowotnej w Polsce. Studium polityki zdrowotnej, Kraków 1998, s. 163.

${ }^{33}$ Pomimo że ten przejaw demokratyzacji życia społecznego nie był odpowiedzią na potrzeby ogółu osób korzystających z usług zakładów opieki zdrowotnej - tak np. J. Indulski, L. Dawydzik, Powszechne ubezpieczenie zdrowotne - ograniczenia i problemy, "Zdrowie Publiczne" 1997, nr 12, s. 290.

${ }^{34}$ Dz.U. Nr 30, poz. 158 ze zm. 
1991 r. w sprawie Kodeksu Etyki Lekarskiej35 (KEL), w którym zawarto rozdział "Prawa pacjenta”, co stanowiło novum w tym zakresie w porównaniu z treścią dotychczasowych kodeksów i odpowiadało tendencjom międzynarodowych kodeksów deontologicznych ${ }^{36}$. Równie zasadnicze rozwiązania w tym zakresie normowała Ustawa z dnia 19 kwietnia 1991 r. powołująca po raz pierwszy w Polsce samorząd pielęgniarek i położnych ${ }^{37}$.

Przepisy dotyczące użytkowników zakładów służby zdrowia wynikały także z Ustawy z dnia 30 sierpnia 1991 r. o zakładach opieki zdrowotnej ${ }^{38}$, którą zniesiono monopol władz publicznych ${ }^{39}$ na ich prowadzenie przez nieograniczony krąg podmiotów ${ }^{40}$. Pozwoliło to na wprowadzenie zasad rynku regulowanego i rozszerzenie prawa do dokonywania wyboru świadczeniodawcy przez pacjentów oraz stworzono nowe: rozwiązania instytucjonalne, instrumenty regulacji, zasady gospodarki finansowej w sferze opieki zdrowotnej i rozwiązania w stosunkach zakład opieki zdrowotnej - pacjent ${ }^{41}$. Regulując pierwszy raz podmiotowe uprawnienia pacjenta jako użytkownika każdego zakładu opieki zdrowotnej, formalnie stworzono gwarancje ich respektowania, gdzie określone prawa podmiotowe mogła zmienić, znieść lub ograniczyć jedynie ustawa. Zgodnie z art. 19 tekstu pierwotnego u.z.o.z.: "[p]acjent ma prawo do: świadczeń zdrowotnych odpowiadających wymaganiom wiedzy medycznej, wyrażania zgody lub odmowy jej udzielenia na określone świadczenia - po uzyskaniu odpowiedniej informacji, uzyskania informacji o swoim stanie zdrowia, poszanowania jego intymności i godności w czasie udzielania mu świadczeń zdrowotnych, umierania w spokoju i godności". Regulację tę, określaną w komentarzach przez

${ }^{35}$ M. Dercz, T. Rek, Ustawa o zakładach..., s. 123. KEL nie jest aktem prawnym powszechnie obowiązującym, lecz zbiorem reguł postępowania lekarza w życiu zawodowym, uwzględniającym jego relacje z pacjentem. Co więcej, są tam również zawarte inne reguły, wykraczające poza relację z pacjentem, np. relacje pomiędzy lekarzami lub relacje ze społeczeństwem.

${ }^{36}$ Por. np. J. Bujny, op. cit., s. 8; D. Karkowska, Prawa pacjenta, s. 202.

${ }^{37}$ Ustawa z dnia 19 IV 1991 r. o samorządzie pielęgniarek i położnych (Dz.U. Nr 41, poz. 178 ze zm.).

${ }^{38}$ Dz.U. Nr 9, poz. 408, dalej „u.z.o.z.”.

${ }^{39}$ Z. Leoński, Komentarz do art. 1-19, w: Z. Leoński, K. Wojtczak, Komentarz do ustawy o zakładach opieki zdrowotnej, Warszawa-Poznań 1993, s. 19.

${ }^{40}$ Dopuszczając funkcjonowanie publicznych zakładów w formie zakładów samodzielnych.

${ }^{41}$ Zob. np. B. Kempińska-Mirosławska, Przekształcenia systemowe. Transformacja systemu ochrony zdrowia w Polsce, Warszawa 1998, s. 20. 
Z. Leońskiego ${ }^{42}$ oraz M. Dercza i T. Reka ${ }^{43}$ jako „katalog praw pacjenta”, oceniono jako nieprecyzyjną, niepełną i niewyczerpującą ze względu na użycie nieostrych pojęć podlegających różnym ocenom oraz fakt, że inne ustawy zawierają normy wprost ustanawiające prawa pacjenta ${ }^{44} \mathrm{i}$ że katalog ten nie uwzględnia specyfiki poszczególnych typów zakładów (np. w zakresie psychiatrycznej opieki zdrowotnej ${ }^{45}$ ), która to powinna być uregulowana w poszczególnych regulaminach porządkowych.

Wskazany w art. 19 u.z.o.z. katalog dotyczył pacjentów korzystających ze wszystkich form zakładów opieki zdrowotnej (publicznych i niepublicznych) z wyłączeniem indywidualnej praktyki lekarskiej. Stąd dla tworzenia przyszłego systemu ochrony interesów i uprawnień pacjenta szczególne znaczenie miało także wprowadzenie dwóch ustaw określających zasady wykonywania zawodów medycznych, tj. Ustawy z dnia 5 lipca 1996 r. o zawodach pielęgniarki i położnej ${ }^{46}$ i już przytaczanej ustawy o zawodach lekarza i lekarza dentysty - będących wyrazem tendencji do nowego uregulowania wykonywania "wolnych" zawodów, w literaturze definiowanych jako "osobiste i samodzielne wykonywanie wewnętrznie spójnego zespołu czynności o charakterze intelektualnym, wymagających wysokich kwalifikacji (wiedzy i praktyki), systematycznie, w zamian za honorarium bezinteresownie ustalone, służące zapewnieniu świadczeń lub usług klientom oraz ochronie istotnych wartości interesu ogólnego zgodnie z obowiązującymi normami prawnymi, zasadami etycznymi i deontologicznymi" ${ }^{\prime 7}$.

W stosowanej w Polsce doktrynalnej klasyfikacji gałęzi prawa pacjenta przypisano zatem do prawa administracyjnego. Termin

${ }^{42}$ Z. Leoński, Komentarz do art. 1-19, s. 34.

${ }^{43}$ M. Dercz, T. Rek, Ustawa o zakładach..., s. 123.

${ }^{44}$ Na przykład Ustawa z dnia 7 I 1993 r. o planowaniu rodziny, ochronie płodu ludzkiego i warunkach dopuszczalności przerywania ciąży (Dz.U. Nr 17, poz. 78 ze zm.) - regulująca prawo kobiety do uzyskania informacji o diagnostyce prenatalnej i wyrażenia zgody na zabieg przerwania ciąży; Ustawa z dnia 26 X 1995 r. o pobieraniu i przeszczepianiu komórek, tkanek i narządów (Dz.U. Nr 138, poz. 682 ze zm.) - normująca zagadnienia transplantacji ex mortuo i ex vivo z uwzględnieniem prawa do poszanowania integralności osoby ludzkiej.

${ }^{45}$ Ustawa z dnia 19 VIII 1994 r. o ochronie zdrowia psychicznego (tekst jedn. Dz.U. 2018, poz. 1878) ustanowiła zagadnienia z zakresu ochrony zdrowia psychicznego, w tym ochronę praw pacjentów, choć ustawodawca nie posługuje się w niej bezpośrednio sformułowaniem "prawa pacjenta".

${ }^{46}$ Dz.U. Nr 91, poz. 410 ze zm.

${ }^{47} \mathrm{~K}$. Wojtczak, Administracyjnoprawna reglamentacja wolnych zawodów, w: Rola materialnego prawa administracyjnego a ochrona praw jednostki, pod red. Z. Leońskiego, Poznań 1998, s. 105. 
„prawa pacjenta" i ich katalog uregulowany w obowiązującej wówczas u.z.o.z., z dniem 5 grudnia 1997 r. na mocy art. 1 pkt 20 Ustawy z dnia 20 czerwca 1997 r. o zmianie ustawy o zakładach opieki zdrowotnej oraz o zmianie niektórych innych ustaw ${ }^{48}$ poszerzono $\mathrm{w}$ stosunku do wersji pierwotnej o trzy prawa. Zgodnie bowiem z art. 19 ust. 3 "[w] zakładach opieki zdrowotnej przeznaczonych dla osób wymagających całodobowych lub całodziennych świadczeń zdrowotnych pacjent ma również prawo do: (1) dodatkowej opieki pielęgnacyjnej sprawowanej przez osobę bliską lub inną wskazaną przez siebie; (2) kontaktu osobistego, telefonicznego lub korespondencyjnego z osobami z zewnątrz; (3) opieki duszpasterskiej". Zakład zobowiązano do stworzenia warunków urzeczywistniania i respektowania praw pacjenta, a podstawowy stosunek w ochronie zdrowia to relacja pacjent - zakład opieki zdrowotnej.

Nie ulega wątpliwości, że rozproszenie praw pacjenta w polskim porządku prawnym $\mathrm{w}$ wielu przepisach prawnych nakładających obowiązki na różne podmioty uczestniczące w udzielaniu świadczeń zdrowotnych sprawiło, iż (1) nie były one znane pacjentom lub w należyty sposób nie były rozumiane, a (2) zagadnienie praw pacjenta i ich ochrony wymagało kompleksowego unormowania w jednym akcie prawnym - ustawie ${ }^{49}$. Potrzebę ujednolicenia praw pacjenta częściowo zrealizował Minister Zdrowia i Opieki Społecznej w formie komunikatu z dnia 11 grudnia 1998 r., zlecając wszystkim świadczeniodawcom ${ }^{50}$ przekazanie do publicznej informacji Karty Praw Pacjenta ${ }^{51}$ (tj. zbioru (pozbawionego waloru aktu normatywnego) praw pacjenta wynikającego z obowiązujących aktów prawnych ${ }^{52}$ ). Zgodnie z Kartą „[p]rawem pacjenta jest uprawnienie przysługujące w równym stopniu każdemu człowiekowi z tytułu korzystania ze świadczeń zdrowotnych. [...]. Każdy pacjent powinien znać swoje prawa i umieć z nich korzystać".

${ }^{48}$ Dz.U Nr 104, poz. 661. Zob. dodany rozdział 1a ustawy.

${ }^{49}$ Podstawowej krytyce poddawano bowiem stosowanie regulaminu porządkowego zakładu opieki zdrowotnej jako narzędzia wprowadzania praw pacjenta do tych podmiotów.

${ }^{50}$ Były to: zakłady opieki zdrowotnej, lekarze, pielęgniarki, położne wykonujące indywidualną praktykę oraz inne osoby i podmioty udzielające czy uczestniczące w sprawowaniu opieki zdrowotnej.

${ }^{51}$ Komunikat MZiOS z dnia 11 XII 1998 r., http://www.zdrowie.med.pl (dostęp: 10 III 2020).

${ }^{52}$ Pomimo uaktualnienia Karty w 2007 r. nadal brakowało ustawy całościowo regulującej prawa pacjenta. 
Inne mankamenty towarzyszące kształtującym się prawom pacjenta wynikały także ze zmian w ustawodawstwie w zakresie systemu ubezpieczeń, gdzie pod wpływem uwarunkowań polityczno-ekonomicznych wprowadzono ograniczenia $w$ dotychczasowych zasadach państwa opiekuńczego, umożliwiając oficjalną partycypację społeczeństwa w części kosztów funkcjonowania opieki zdrowotnej ${ }^{53}$, co wiązało się z trudnościami finansowymi państwa poprzez ograniczanie realizacji formalnego prawa obywateli do powszechnych, bezpłatnych świadczeń zdrowotnych $^{54}$. Dlatego Ministerstwo Zdrowia i Opieki Społecznej przygotowało projekt ustawy o zakresie świadczeń zdrowotnych gwarantowanych przez państwo ze środków publicznych ${ }^{55}$, mającej uporządkować zasady dostępu do świadczeń zdrowotnych, m.in. poprzez wprowadzenie opłat za niektóre rodzaje świadczeń zdrowotnych bądź usługi związane z przebiegiem leczenia. Projektowana ustawa nie weszła jednak w życie, choć jej podstawowe założenia stały się częścią Ustawy z dnia 6 lutego 1997 r. o powszechnym ubezpieczeniu zdrowotnym ${ }^{56}$, której istota polegała na próbie przekształcenia stosunku obywatel - państwo $\mathrm{w}$ trójstronny stosunek ubezpieczony - kasa powszechnego ubezpieczenia zdrowotnego (kasa chorych ${ }^{57}$ ) - świadczeniodawca. Kasy odpowiadały za finansowanie świadczeń, a nie za ich dostarczanie. Ustawa nie zawierała sformułowania "prawa pacjenta”, choć regulowała prawo osób ubezpieczonych do opieki zdrowotnej, prawo wyboru kasy chorych i świadczeniodawcy (art. 60), prawo odwołania się od decyzji kasy do sądu pracy i ubezpieczeń zdrowotnych (art. 147) i sądu cywilnego (art. 150). W kasach chorych powołano tymczasowo stanowiska Rzeczników Praw Pacjenta, które mimo potrzeby nie stanowiły w praktyce skutecznej ochrony pacjenta ${ }^{58}$. Spowodowało to, że w celu powołania

${ }^{53}$ Na przykład J. Halik, Społeczeństwo polskie wobec opłat za niektóre świadczenia służby zdrowia, "Antidotum" 1992, nr 4, s. 37.

${ }^{54}$ Zob. M. Maśkiewicz, Spojrzenie na budżet ochrony zdrowia, "Zdrowie Publiczne" 1993, nr 8; E. Kulesza, Uwagi do projektu ustawy o zasadach świadczeń gwarantowanych przez państwo ze środków publicznych, "Antidotum” 1994, nr 11, s. 9.

${ }^{55}$ Druk sejmowy nr 1168/II kadencja z dnia 19 VII 1995 r.

${ }^{56}$ Dz.U. Nr 28, poz. 153 ze zm. Ustawa ta weszła w życie w dniu 1 I 1999 r.

${ }^{57}$ Funkcjonowanie kas chorych oparto na samorządności i samofinansowaniu, a gwarancje instytucjonalne miały zapewnić ubezpieczonym właściwy poziom i jakość świadczeń zdrowotnych.

${ }^{58}$ Rola rzeczników objęła wskazanie pacjentom drogi składania skargi na podstawie jej analizy, możliwość zwrócenia uwagi dyrektorów kas chorych na świadczeniodawców rażąco naruszających prawa pacjenta. 
wyspecjalizowanej instytucji działającej na rzecz ochrony praw pacjentów Minister Zdrowia wydał dwa zarządzenia: z dnia 28 grudnia 2001 r. w sprawie utworzenia Biura Rzecznika Praw Pacjenta ${ }^{59}$ i z dnia 27 października 2005 r. w sprawie Biura Praw Pacjenta ${ }^{60}$.

Należy nadmienić, że w wyniku dalszej reformy systemu ubezpieczeń uchwalono Ustawę z dnia 23 stycznia 2003 r. o powszechnym ubezpieczeniu w Narodowym Funduszu Zdrowia ${ }^{61}$, którą po uznaniu podstawowych jej przepisów za niezgodne z Konstytucją RP, zastąpiła przytaczana już Ustawa z dnia 27 sierpnia 2004 r. o świadczeniach opieki zdrowotnej finansowanych ze środków publicznych, stanowiąca obecnie podstawową formę ochrony zdrowia i finansowania ze środków publicznych świadczeń opieki zdrowotnej w Polsce.

\subsection{Prawa pacjenta - stan obecny}

Podstawowe prawa pacjenta określa ustawa o prawach pacjenta i Rzeczniku Praw Pacjenta ${ }^{62}$. Zgodnie z założeniem ustawodawcy regulacja ta odgrywa ważną rolę w uporządkowaniu i stworzeniu nowych gwarancji dotyczących praw pacjenta, wpływa na poprawę warunków leczenia i zwiększenia świadomości społecznej w zakresie prawnej ochrony pacjentów, tj. szczególnej kategorii osób.

Wejście w życie ustawy o prawach pacjenta wyznacza katalog praw pacjenta, który odnosi się do pacjentów korzystających ze świadczeń zdrowotnych udzielanych przez każdy podmiot udzielający świadczeń zdrowotnych i przez każdą osobę wykonującą zawód medyczny. Przepisy prawa wprowadzają określone obowiązki (zakazy, nakazy ${ }^{63}$ ) lub dozwolenia w celu ochrony praw i wolności człowieka podczas „zwracania się o" lub "korzystania z" świadczeń zdrowotnych. Regulacje te

${ }^{59}$ Dz.Urz. MZ Nr 13, poz. 83.

${ }^{60}$ Dz.Urz. MZ Nr 17, poz. 89.

${ }^{61}$ Dz.U. Nr 45, poz. 391 ze zm.

${ }^{62}$ Ustawa ta wprowadziła także instytucję Rzecznika Praw Pacjenta, będącego centralnym organem administracji rządowej właściwym w sprawach ochrony praw pacjentów. Rzecznik jest powoływany i odwoływany przez Prezesa Rady Ministrów spośród osób wyłonionych w drodze otwartego i konkurencyjnego naboru. Prezes Rady Ministrów sprawuje nadzór nad działalnością Rzecznika, który to wykonuje swoje zadania przy pomocy Biura Rzecznika Praw Pacjenta.

${ }^{63}$ Chodzi tu o możliwość ograniczenia korzystania z praw pacjenta (art. 5 u.p.p.) czy wprowadzenie ponoszenia opłat za realizację określonych praw (art. 28 i 35 u.p.p.). 
powinny być formułowane za pomocą zwrotów na tyle precyzyjnych, żeby nie dochodziło do ich różnej interpretacji ${ }^{64}$.

Konstrukcja praw pacjenta ma charakter administracyjnoprawny ${ }^{65}$. Przy czym stosunki łączące pacjenta z podmiotami udzielającymi świadczeń zdrowotnych moga już mieć różnorodny charakter. Jeżeli świadczenie jest udzielane przez zakład - obecnie podmiot leczniczy - to stosunek między pacjentem a świadczeniodawcą ma charakter administracyjnoprawny. Gdy pacjent korzysta ze świadczeń zdrowotnych udzielanych przez innego świadczeniodawcę, to ów stosunek jest nawiązywany pomiędzy pacjentem, świadczeniodawcą i NFZ. W sytuacji gdy świadczeniodawca nie zawarł umowy z NFZ, to udzielanie świadczeń zdrowotnych odbywa się na podstawie umowy cywilnoprawnej.

Ustawa o prawach pacjenta, konkretyzując konstytucyjne prawo do ochrony zdrowia, normuje rozbudowany katalog praw pacjenta, wyodrębniając aktualnie czternaście praw ${ }^{66}$, z których w kontekście niniejszego opracowania najistotniejsze znaczenie ma prawo pacjenta do świadczeń zdrowotnych uregulowane w art. 6 i 8 u.p.p. ${ }^{67}$ Dokonując analizy tych przepisów, nie sposób nie odwołać się do innych regulacji mających swoje "lustrzane odbicie" w u.p.p., a dotyczących zawodów medycznych (przede wszystkim zawodu lekarza), warunków udzielania i zakresu świadczeń opieki zdrowotnej finansowanych ze środków publicznych czy ogólnych zasad wykonywania działalności

${ }^{64}$ D. Karkowska, Prawa pacjenta, s. 210.

${ }^{65}$ Szerzej zob. J. Bujny, op. cit., s. 27-32. Autor jednocześnie wskazuje, że prawa pacjenta regulowane sa przez akty prawa administracyjnego $\mathrm{w}$ zakresie korzystania z rzeczy powszechnego użytku bądź reglamentacji wolnych zawodów, do których należy zawód lekarza.

${ }^{66}$ Są to: (1) prawo pacjenta do świadczeń zdrowotnych, (2) prawo pacjenta do informacji, (3) prawo pacjenta do zgłaszania działań niepożądanych produktów leczniczych, (4) prawo pacjenta do tajemnicy informacji z nim związanych, (5) prawo pacjenta do wyrażenia zgody na udzielenie świadczeń zdrowotnych, (6) prawo do poszanowania intymności i godności pacjenta, (7) prawo pacjenta do dokumentacji medycznej, (8) prawo pacjenta do zgłoszenia sprzeciwu wobec opinii albo orzeczenia lekarza, (9) prawo pacjenta do poszanowania życia prywatnego i rodzinnego, (10) prawo pacjenta do opieki duszpasterskiej, (11) prawo pacjenta do przechowania rzeczy wartościowych w depozycie, (12) prawo wystapienia do Rzecznika Praw Pacjenta, (13) prawo do ochrony zbiorowych praw pacjenta, (14) prawo pacjenta do wystąpienia z wnioskiem do wojewódzkiej komisji orzekającej do spraw orzekania o zdarzeniach medycznych.

${ }^{67}$ Ominięty tu art. 7 ust. 1-2 u.p.p. stanowi, że pacjent ma prawo do natychmiastowego udzielenia świadczeń zdrowotnych ze względu na zagrożenie zdrowia lub życia. W przypadku porodu pacjentka ma prawo do uzyskania świadczeń związanych z porodem. 
leczniczej. Zgodnie z art. 6 ust. 1 u.p.p. pacjent ma prawo do świadczeń zdrowotnych odpowiadających wymaganiom aktualnej wiedzy medycznej. Przepis ten pozwala pacjentowi oczekiwać, że metody leczenia wobec niego zastosowane będą aktualne i sprawdzone, oraz wyłącza możliwość stosowania metod zdezaktualizowanych o charakterze pozamedycznym. Poza tym dotyczy niekwestionowanego warunku podejmowania czynności zgodnie z prawem (lege artis). Podejmowanie czynności zawodowych odpowiadających wymaganiom aktualnej wiedzy medycznej wynika także z innych przepisów, w których ujęte jest jako obowiązek danego zawodu medycznego. Zgodnie bowiem z fragmentem art. 4 u.z.l. lekarz ma obowiązek wykonywać zawód zgodnie ze wskazaniami aktualnej wiedzy medycznej ${ }^{68}$, dostępnymi mu metodami i środkami zapobiegania, rozpoznawania i leczenia chorób. Warto wskazać w tym zakresie również przyrzeczenie lekarskie stanowiące wstęp do KEL, zawierające przepis: „przyrzekam [...] stale poszerzać swą wiedzę lekarską" ${ }^{\prime 9}$. Co więcej, zgodnie z art. $56 \mathrm{KEL}$ powinnością każdego lekarza jest stałe uzupełnianie i doskonalenie swej wiedzy i umiejętności zawodowych, a także przekazywanie ich swoim współpracownikom.

Według art. 6 ust. 2 u.p.p. pacjent ma prawo w sytuacji ograniczonych możliwości udzielenia odpowiednich świadczeń zdrowotnych do przejrzystej, obiektywnej, opartej na kryteriach medycznych procedury ustalającej kolejność dostępu do tych świadczeń. W tym zakresie Sąd Apelacyjny w Warszawie w wyroku z dnia 29 czerwca 2004 r. podniósł, że m.in. z powodu ograniczoności środków finansowych ustawodawca wprost przewidział istnienie kolejki medycznej, w przypadku gdy jest to możliwe ze względu na stan zdrowia ${ }^{70}$. Zasada ta ma charakter ogólny i musi być stosowana niezależnie od sposobu finansowania oraz miejsca udzielania świadczenia. Szczegółowe zasady regulujące wypełnianie procedury ustalającej kolejność dostępu do świadczeń dotyczą świadczeń szpitalnych i specjalistycznych świadczeń w ambulatoryjnej opiece zdrowotnej finansowanych ze środków publicznych. Zasady

${ }^{68}$ Co do szczegółowej interpretacji pojęcia "aktualna wiedza medyczna” zob. np. M. Boratyńska, Z. Konieczniak, Prawa pacjenta, Warszawa 2001, s. 173; Ustawa o zawodach lekarza i lekarza dentysty. Komentarz, pod red. E. Zielińskiej, Warszawa 2008, s. 344.

${ }^{69}$ Ten obowiązek kodeksy etyczne formułowały zawsze dla zawodu lekarza. Więcej odnośnie do kodeksów etycznych samorządów zawodów medycznych zob. D. Karkowska, Ustawa o prawach pacjenta..., s. 103-107.

${ }^{70}$ Wyrok Sądu Apelacyjnego w Warszawie z 29 VI 2004 r., sygn. I ACa 1/04, Legalis nr 69009. 
prowadzenia list oczekujących regulują art. 20-24 u.ś.o.z. Warto tu dodać, że listy te prowadzi się w sposób zapewniający poszanowanie zasady sprawiedliwego, równego, niedyskryminującego i przejrzystego dostępu do świadczeń opieki zdrowotnej oraz zgodnie z kryteriami medycznymi (art. 20 ust. 5 u.ś.o.z.). Ponadto Minister Zdrowia określił $\mathrm{w}$ drodze rozporządzenia kryteria medyczne, jakimi powinni się kierować świadczeniodawcy, umieszczając świadczeniobiorców na listach oczekujących ${ }^{71}$. Regulacje tego typu wynikają także z art. $22 \mathrm{KEL}$, zgodnie z którym w przypadkach wymagających szczególnych form diagnostyki, terapii lub działań zapobiegawczych, które nie mogą być zastosowane równocześnie u wszystkich potrzebujących, lekarz ustalający kolejność pacjentów powinien opierać się na kryteriach medycznych.

Pacjent ma także prawo żądać, aby udzielający mu świadczeń zdrowotnych (a) lekarz zasięgnął opinii innego lekarza lub zwołał konsylium lekarskie; (b) pielęgniarka/położna zasięgnęła opinii innej pielęgniarki/ położnej (art. 6 ust. 3 u.p.p.). Adresatem przepisu jest każdy pacjent znajdujący się w różnych sytuacjach zdrowotnych. Jest to pierwsza tego typu regulacja w Polsce umożliwiająca żądanie weryfikacji dotychczasowej decyzji lekarza ${ }^{72}$ i wpływająca na poprawę jakości wykonywanej usługi zdrowotnej. Możliwość zasięgnięcia dodatkowej opinii lub zwołania konsylium reguluje także art. 37 u.z.l. W świetle tych przepisów w razie wątpliwości diagnostycznych lub terapeutycznych lekarz z własnej inicjatywy bądź na wniosek pacjenta lub jego przedstawiciela ustawowego, jeżeli uzna to za uzasadnione w świetle wymagań wiedzy medycznej, powinien zasięgnąć opinii właściwego lekarza specjalisty lub zorganizować konsylium lekarskie. Podobne rozwiązanie dotyczące konsultacji innego lekarza wynika z art. 54 KEL, przy czym opinia konsultanta ma charakter tylko doradczy, za całość postępowania odpowiada lekarz prowadzący leczenie.

Poza tym zgodnie $z$ art. 8 u.p.p. zd. 1 pacjent ma prawo do świadczeń zdrowotnych udzielanych z należytą starannością przez podmioty udzielające świadczeń zdrowotnych $\mathrm{w}$ warunkach odpowiadających określonym w odrębnych przepisach wymaganiom fachowym i sanitarnym. Podobna regulacja dotycząca obowiązku zachowania należytej staranności podczas wykonywania zawodu lekarza wynika $\mathrm{z}$ art. 4 u.z.l. oraz $\mathrm{z}$ art. $8 \mathrm{KEL}$, zgodnie $\mathrm{z}$ którym lekarz powinien

\footnotetext{
${ }^{71}$ Zob. Rozporządzenie Ministra Zdrowia z dnia 26 IX 2005 r. (Dz.U. Nr 200, poz. 1661).

${ }^{72}$ Przepis ten stosuje się również do pielęgniarki (położnej).
} 
przeprowadzać wszelkie postępowanie diagnostyczne, lecznicze i zapobiegawcze z należytą starannością, poświęcając im niezbędny czas. Ciekawy jest w tym kontekście pogląd M. Nesterowicza, który podnosi, że "od lekarzy wymaga się staranności wyższej niż przeciętna z uwagi na przedmiot zabiegów, którym jest człowiek i skutki, które często są nieodwracalne" ${ }^{\prime \prime 3}$. Jeżeli chodzi natomiast o warunki, w jakich udzielane są świadczenia zdrowotne, to warto tu uwzględnić regulacje dotyczące działalności leczniczej ${ }^{74}$. Stosownie bowiem do art. 2 pkt 5 u.d.l. „podmiot wykonujący działalność leczniczą" oznacza podmiot leczniczy przyjmujący różne formy organizacyjne $\mathrm{w}$ zakresie, $\mathrm{w}$ jakim wykonują one działalność leczniczą ${ }^{75}$, oraz lekarza, pielęgniarkę lub fizjoterapeutę wykonujących zawód w ramach działalności leczniczej jako praktykę zawodową ${ }^{76}$. Co więcej, zgodnie $\mathrm{z}$ art. 17 u.d.l. podmiot leczniczy jest obowiązany spełniać następujące warunki: (1) posiadać pomieszczenia lub urządzenia odpowiadające określonym wymaganiom ${ }^{77}$; (2) używać i utrzymywać wyroby medyczne; (3) zapewniać udzielanie świadczeń zdrowotnych wyłącznie przez osoby wykonujące zawód medyczny oraz spełniające wymagania zdrowotne określone w odrębnych przepisach; (4) zawrzeć umowę ubezpieczenia - w zakresie odpowiedzialności cywilnej. Bez wątpienia, tak określone standardy będące pomocnym narzędziem w procesie podejmowania decyzji o udzieleniu świadczenia zdrowotnego pacjentowi mają istotny wpływ na jakość tych świadczeń. Należy zwrócić jednak uwagę, że podmiot udzielający świadczeń

${ }^{73}$ M. Nesterowicz, Wyrok Sadu Najwyższego z dnia 1 grudnia 1998 r., III CKN 741/98, OSN 6/1999, poz. 112. Glosa, "Prawo i Medycyna” 2000, nr 6-7, s. 168.

${ }^{74}$ Przepis art. 1 u.d.l. określa: (1) zasady wykonywania działalności leczniczej; (2) zasady funkcjonowania podmiotów wykonujących działalność leczniczą niebędących przedsiębiorcami; (3) zasady prowadzenia rejestru podmiotów wykonujących działalność leczniczą; (4) normy czasu pracy pracowników podmiotów leczniczych; (5) zasady sprawowania nadzoru nad wykonywaniem działalności leczniczej oraz podmiotami wykonującymi działalność leczniczą.

${ }^{75}$ Zamknięty katalog tych podmiotów wynika z art. 4 u.d.l.

${ }^{76}$ Stosownie do art. 5 ust. 1 i 3 u.d.l. lekarze, pielęgniarki i fizjoterapeuci mogą wykonywać swój zawód w ramach działalności leczniczej na zasadach określonych w ustawie oraz w przepisach odrębnych, po wpisaniu do rejestru podmiotów wykonujących działalność leczniczą. Przy czym wykonywanie zawodu w ramach praktyki zawodowej nie jest prowadzeniem podmiotu leczniczego.

${ }_{77}$ Zgodnie z art. 22 ust. 1-2 u.d.l. pomieszczenia i urządzenia podmiotu wykonującego działalność leczniczą odpowiadają wymaganiom odpowiednim do rodzaju wykonywanej działalności leczniczej oraz zakresu udzielanych świadczeń zdrowotnych. Wymagania te dotyczą w szczególności warunków: (1) ogólnoprzestrzennych; (2) sanitarnych; (3) instalacyjnych. 
zdrowotnych jest zobowiązany do starannego działania, a nie do wyleczenia. Przy czym "[p]rawo do leczenia to nie to samo co do bycia wyleczonym"78.

Zgodnie $z$ art. 8 u.p.p. zd. 2 przy udzielaniu świadczeń zdrowotnych osoby wykonujące zawód medyczny kierują się zasadami etyki zawodowej określonymi przez właściwe samorządy zawodów medycznych. Regulacja ta jest kolejnym przykładem "lustrzanego odbicia” wynikającego zarówno z u.z.l., jak i samego KEL. Potwierdza ponadto, że istotny wpływ na sytuację prawną pacjenta wywierają tradycja prawna i kodeksowe zasady etyki samorządów zawodów medycznych.

\subsection{Definicja pacjenta}

Poza samym katalogiem praw pacjenta u.p.p. zawiera definicję legalną pacjenta. Uwaga jest o tyle istotna, że do czasu wejścia w życie przedmiotowej ustawy przepisy polskie nie zawierały pojęcia "pacjent"79. Termin ten wywodzi się od łacińskiego słowa patiens i oznacza cierpiącego $^{80}$. Słownikowa definicja pojęcia wskazuje, że pacjentem jest chory zgłaszający się do lekarza lub pozostający pod jego opieką ${ }^{81}$. Wydaje się, że pierwotne rozumienie tego pojęcia byłoby współcześnie zbyt wąskie, ograniczałoby bowiem krąg podmiotów, którym przysługują prawa pacjenta, do osób mniej lub bardziej dotkniętych chorobą bądź innym zaburzeniem stanu zdrowia. Tymczasem pacjentem może być (i często jest) osoba w pełni zdrowa. W ujęciu doktryny odnosi się do tego stanowiska np. D. Ponczek, wskazując na osoby zdrowe zwracające się do lekarza po poradę w celach profilaktycznych, dawców komórek, tkanek i narządów pobieranych w celach transplantacyjnych za ich życia, którzy dopiero po dokonaniu transplantacji doznają trwałego uszczerbku na zdrowiu ${ }^{82}$. Wąskie rozumienie tego pojęcia ogranicza możliwe relacje do typu pacjent - lekarz, co zdecydowanie nie wyczerpuje zakresu możliwych stosunków, których pacjent jest stroną ${ }^{83}$.

\footnotetext{
${ }^{78}$ M. Nesterowicz, Prawo medyczne, Toruń 2007, s. 37.

${ }^{79}$ Szerzej: J. Bujny, op. cit., s. 9.

${ }^{80}$ W. Kopaliński, Stownik wyrazów obcych i zwrotów obcojezzycznych z almanachem, Warszawa 1999, s. 368.

${ }^{81}$ Stownik jezyka polskiego, t. 2, Warszawa 1979, s. 578.

${ }^{82}$ D. Ponczek, Prawa pacjenta w Polsce, Łódź 1999, s. 7. Podobnie M. Boratyńska, P. Konieczniak, op. cit., s. 12-13.

${ }^{83}$ M. Dercz, T. Rek, Ustawa o zakładach..., s. 121.
} 
W literaturze prawniczej K. Wojtczak poddała przyjęte pojęcie gruntownej analizie i zaproponowała zdefiniowane pojęcie "pacjen$\mathrm{t}^{\prime \prime 84}$ oparte na kategorii zdrowia rozumianego jako stan zupełnej pomyślności fizycznej, umysłowej i społecznej, a nie jedynie jako brak choroby lub ułomności ${ }^{85}$. Zgodnie z koncepcją tej autorki pacjentem może być zarówno osoba chora, jak i zdrowa, ponieważ ze świadczeń zdrowotnych korzystać może nie tylko osoba hospitalizowana, czyli ewidentnie dotknięta chorobą pojmowaną jako proces patologiczny wywołujący zaburzenia czynności organizmu ${ }^{86}$, ale także osoba zdrowa profilaktycznie badająca własny stan zdrowia. Motywem korzystania ze świadczeń zdrowotnych przez zdrową osobę może być zarówno troska o własne zdrowie bądź obawa o jego uszczerbek. Według K. Wojtczak pacjentem można zostać niezależnie od tego, jaka forma świadczenia zdrowotnego jest udzielona i jaki jest jego rezultat, oraz bez względu na to, jaki jest rzeczywisty cel osoby oczekującej takiego świadczenia, i to niezależnie od tego, czy prawodawca terminu "pacjent” używa, czy też tego nie czyni ${ }^{87}$. Pojęcie "pacjent" składa się przynajmniej z trzech elementów i odnosi się: (1) wyłącznie do osoby fizycznej, (2) otrzymującej świadczenie zdrowotne bez względu na prawo do jego otrzymania, jak i do osoby, która oczekuje świadczenia zdrowotnego, zgodnie z oparta na kryteriach medycznych procedurą ustalającą kolejność dostępu do tych świadczeń, (3) zawsze do osoby pozostającej z tytułu oczekiwanego lub udzielanego świadczenia zdrowotnego w relacji z osobą wykonującą zawód medyczny, bez względu na to, czy jest ona pracownikiem z.o.z. - obecnie podmiotu leczniczego - czy wykonuje zawód poza nim. Zamknięty zbiór podmiotów uprawnionych do udzielania świadczeń zdrowotnych oznacza, że pacjentem nie jest osoba korzystająca $\mathrm{w}$ celu poprawy zdrowia $\mathrm{z}$ usług np. bioenergoterapeuty lub radiestety.

Podstawą przedstawionej przez K. Wojtczak definicji pacjenta jest założenie korzystania ze świadczeń zdrowotnych ${ }^{88}$, ponadto pozostaje ona w relacji z propozycją Światowej Organizacji Zdrowia. W deklaracji o Promocji Praw Pacjenta w Europie ${ }^{89}$ zdefiniowano pacjenta jako osobę

${ }^{84}$ K. Wojtczak, Rozważania nad pojęciem pacjenta, w: Jednostka w demokratycznym państwie prawa, pod red. J. Filipka, Bielsko-Biała 2003, s. 744-750.

${ }^{85}$ Definicja "zdrowia” za Konstytucją Światowej Organizacji Zdrowia z dnia 22 VII 1946 r. (Dz.U. 1948 Nr 61, poz. 477 ze zm.).

${ }^{86}$ Stownik jezzyka polskiego, t. 1, Warszawa 1978, s. 273.

${ }^{87}$ K. Wojtczak, Rozważania..., s. 746-747, 750.

${ }^{88}$ Ibidem, s. 745.

${ }^{89}$ Przyjęto ją w dniach 28-30 III 1994 r. w Amsterdamie. 
korzystającą ze świadczeń medycznych niezależnie od tego, czy jest to osoba chora czy zdrowa ${ }^{90}$. Do tej definicji nawiązują również M. Dercz i T. Rek, którzy twierdza, że „pacjentem” jest każda osoba - niezależnie od tego, czy jest dotknięta chorobą czy też w pełni zdrowa - korzystająca z usług (konsultacji) medycznych lub wobec której podejmuje się jakąkolwiek interwencję medyczna, nawet niemającą charakteru leczniczego ${ }^{91}$.

Obecnie pojęcie to uregulowano w art. 3 ust. 1 pkt 4 u.p.p. Zgodnie z tym unormowaniem pacjent to osoba zwracająca się o udzielenie świadczeń zdrowotnych lub korzystająca ze świadczeń zdrowotnych udzielanych przez podmiot udzielający świadczeń zdrowotnych lub osobę wykonującą zawód medyczny. Ustawodawca, definiując pojęcie "pacjent", tym samym uporządkował zakres podmiotów udzielających świadczeń zdrowotnych. Ze względu na możliwość uzyskania przez pacjenta opieki od wielu podmiotów omawiane pojęcie należy rozumieć szeroko, jako każdą osobę korzystającą z opieki zdrowotnej bez względu na to, kto tę opiekę świadczy ${ }^{92}$.

Przyjęta legalna definicja pozwala na wyodrębnienie kilku elementów. Pojęcie "pacjent" odnosi się wyłącznie do osoby fizycznej, co oznacza, że pacjentem jest "każda osoba”, „każdy człowiek”. Ta osoba "zwraca się o możliwość skorzystania” lub "już korzysta” ze świadczeń zdrowotnych bez względu na posiadanie lub nie uprawnień do świadczeń opieki zdrowotnej finansowanych ze środków publicznych. Pojęcie "pacjent" odnosi się do osoby pozostającej z tytułu oczekiwanego lub udzielanego świadczenia zdrowotnego w relacji do podmiotu udzielającego świadczeń zdrowotnych lub osoby wykonującej zawód medyczny.

Ustawa o prawach pacjenta, używając terminu "pacjent”, dokonuje pewnego zróżnicowania tej szczególnej kategorii osób. Wskazuje na określone grupy pacjentów, w odniesieniu do których posługuje się takimi określeniami, jak: „pacjent małoletni” (art. 9, 17), „pacjent ubezwłasnowolniony” (art.17, 22), "pacjent niezdolny do świadomego wyrażenia zgody" (art. 17, 22), "pacjent znajdujący się w stanie terminalnym" (art. 20) czy "pacjentka w warunkach ciąży, porodu i połogu” (art. 34). Co ważne, reguluje tylko legalną definicję pojęcia "pacjent" i co do zasady odnosi się do pełnoletniego pacjenta. Niektóre z podanych kategorii wskazują zaś na sytuację, w jakiej pacjent się znajduje,

${ }^{90}$ Promotion of the Rights of patients in Europe, Kluwer Law International 1995, s. 44 (Patient('s): user(s) of health care services, wheather healthy or sick).

${ }^{91}$ M. Dercz, T. Rek, Prawa dziecka..., s. 7.

92 D. Karkowska, Prawa Pacjenta, s. 253. 
nie podając legalnej definicji tych pojęć. Należy ponadto zauważyć, że ustawa ta przytacza definicje opiekuna faktycznego ${ }^{93}$ i osoby bliskiej ${ }^{94}$. Inne określenia ukazujące zróżnicowanie pacjentów uregulowane są w przepisach odrębnych (np. termin "pacjent małoletni” stosowany jest do uregulowania ochrony praw dziecka: w rozumieniu art. 2 ust. 1 Ustawy z dnia 6 stycznia 2000 r. o Rzeczniku Praw Dziecka ${ }^{95}$ "dzieckiem jest każda istota ludzka od poczęcia do osiągnięcia pełnoletności", poza tym dla ustalenia kryterium wieku i zdolności do czynności prawnych istotne znaczenie mają regulacje prawa cywilnego, takie jak Ustawa z dnia 23 kwietnia 1964 r. - Kodeks cywilny ${ }^{96}$, Ustawa z dnia 25 lutego 1964 r. - Kodeks rodzinny i opiekuńczy ${ }^{97}$, pozwalające na wyodrębnienie pacjentów małoletnich i ubezwłasnowolnionych oraz osób z nimi powiązanych, czyli przedstawiciela ustawowego i opiekuna prawnego.

\section{Podstawowe pojęcia związane z zagadnieniami uzdrowiskowymi}

Znając definicje praw pacjenta oraz samego pacjenta, warto poddać analizie podstawowe pojęcia związane z zagadnieniami uzdrowiskowymi. Chodzi tu o następujące pojęcia, takie jak: lecznictwo uzdrowiskowe, ochrona zdrowia, świadczenie zdrowotne, gmina uzdrowiskowa, uzdrowisko oraz zakład lecznictwa uzdrowiskowego i urządzenia lecznictwa uzdrowiskowego.

\subsection{Lecznictwo uzdrowiskowe}

Stosownie do art. 2 pkt 1 ustawy uzdrowiskowej lecznictwo uzdrowiskowe oznacza zorganizowaną działalność polegającą na udzielaniu świadczeń

${ }^{93}$ Opiekun faktyczny oznacza osobę sprawująca, bez obowiązku ustawowego, stałą opiekę nad pacjentem, który ze względu na swój wiek, stan zdrowia albo stan psychiczny opieki takiej wymaga (art. 3 ust. 1 pkt 1 ).

${ }^{94}$ Ustawa pierwszy raz zdefiniowała pojęcie osoby bliskiej: zgodnie z art. 3 ust. 1 pkt 2 u.p.p. osoba bliska oznacza małżonka, krewnego lub powinowatego do drugiego stopnia w linii prostej, przedstawiciela ustawowego, osobę pozostającą we wspólnym pożyciu lub osobę wskazaną przez pacjenta.

${ }_{95}$ Tekst jedn. Dz.U. 2020, poz. 141.

96 Tekst jedn. Dz.U. 2019, poz. 1145 ze zm., dalej „k.c.”; zob. art. 12, art. 13 § 1 i art. 15 k.c.

97 Tekst jedn. Dz.U. 2019, poz. 2086, dalej „k.r.o."; zob. art. $10 \S 1$, art. $93 \S 2$, art. 94 $\S 3$, art. 175 k.r.o. 
opieki zdrowotnej z zakresu leczenia uzdrowiskowego albo rehabilitacji uzdrowiskowej, prowadzoną w uzdrowisku przez zakłady lecznictwa uzdrowiskowego albo poza uzdrowiskiem w szpitalach i sanatoriach znajdujących się w urządzonych podziemnych wyrobiskach górniczych, przy wykorzystaniu warunków naturalnych, takich jak: (1) właściwości naturalnych surowców leczniczych, (2) właściwości lecznicze klimatu, w tym talassoterapia i subterraneoterapia, oraz właściwości lecznicze mikroklimatu - a także towarzyszące zabiegi z zakresu fizjoterapii.

Ustawodawca, uwzględniając uwagi przesyłane przez podmioty prowadzące lecznictwo uzdrowiskowe, wojewodów i władze gmin uzdrowiskowych, znowelizowa ${ }^{98}$ ustawę uzdrowiskowa, doprecyzowując niektóre jej przepisy i wdrażając nowe brzmienie definicji lecznictwa uzdrowiskowego. Uszczegółowiono ją poprzez wskazanie dwóch charakterystycznych świadczeń opieki zdrowotnej udzielanych przez zakłady lecznictwa uzdrowiskowego - leczenia albo rehabilitacji uzdrowiskowej. Rehabilitacja uzdrowiskowa oznacza zorganizowaną działalność prowadzoną w uzdrowisku przez zakłady lecznictwa uzdrowiskowego, mającą na celu przywrócenie pacjentowi zdrowia lub możliwej do osiągnięcia dla danego stanu samodzielności ruchowej i społecznej, prowadzoną za pomocą naturalnych surowców leczniczych. Uzupełnienie ustawy o to pojęcie jest związane ze wzrostem zainteresowania programami rehabilitacyjnymi realizowanymi w zakładach lecznictwa uzdrowiskowego. Powyższą definicję rozszerzono, zaliczając do lecznictwa uzdrowiskowego zabiegi z zakresu fizjoterapii. Obowiązujące do tej pory brzmienie przepisu uwzględniało jedynie zabiegi fizykalne, które są jednym z rodzajów zabiegów z zakresu fizjoterapii, które obejmują zespół metod leczniczych wykorzystujących zjawisko reaktywności na bodźce, a do jej działów zalicza się m.in. balneoterapię, kinezyterapię, fizykoterapię i hydroterapię. Wprowadzono ponadto możliwość prowadzenia lecznictwa uzdrowiskowego także poza uzdrowiskiem, w podziemnych, urządzonych wyrobiskach górniczych. Rozwiązanie to umożliwia wykorzystanie naturalnego mikroklimatu podziemnych komór solnych do prowadzenia leczenia albo rehabilitacji uzdrowiskowej. Przedmiotowa regulacja ma na celu rozwój metod leczenia układu oddechowego i alergii.

${ }^{98}$ Zob. Ustawa z dnia 4 III 2011 r. o zmianie ustawy o lecznictwie uzdrowiskowym, uzdrowiskach i obszarach ochrony uzdrowiskowej oraz o gminach uzdrowiskowych oraz niektórych innych ustaw (Dz.U. Nr 73, poz. 390), dalej „uzdrowiskowa ustawa zmieniająca". 
W lecznictwie uzdrowiskowym wykorzystywany jest zespół naturalnych bodźców klimatycznych odpowiednio dawkowanych (klimatoterapia) pod kontrolą lekarza, w połączeniu z różnymi formami wysiłku fizycznego (kinezyterapia) i innymi tworzywami leczniczymi, naturalnymi, jak wody mineralne i borowiny (balneoterapia i peloidoterapia). Kierunek lecznictwa uzdrowiskowego dyktuje szerszy niż dotąd rozwój profilaktyki uzdrowiskowej w celu prowadzenia działalności zapobiegającej powstawaniu schorzeń cywilizacyjnych, będących często ubocznymi skutkami działalności człowieka i rozwijającej się działalności technicznej ${ }^{99}$, a bogactwo różnorodnych elementów kulturowych, obok walorów naturalnych, odgrywa, przy odpowiedniej organizacji lecznictwa, ważną i cenną rolę.

Do najważniejszych wyzwań dla lecznictwa uzdrowiskowego ${ }^{100}$ należą: (1) kompleksowa opieka medyczna (w tym zapewnienie ciągłości i kompleksowości leczenia, optymalizacja sposobu wykorzystania całego potencjału opieki rehabilitacyjnej w Polsce, optymalizacja sposobu finansowania całego systemu opieki rehabilitacyjnej w Polsce); (2) trendy demograficzne - wzrost długości życia; (3) choroby cywilizacyjne; (4) zapobieganie najczęstszym problemom zdrowotnym oraz zaburzeniom rozwoju fizycznego i psychospołecznego dzieci i młodzieży; (5) ograniczanie skutków zdrowotnych spowodowanych czynnikami szkodliwymi w środowisku pracy i zamieszkania.

\subsection{Ochrona zdrowia i świadczenie zdrowotne}

Zgodnie z art. 4 ust. 1 ustawy uzdrowiskowej „[1]ecznictwo uzdrowiskowe jest integralną częścią ochrony zdrowia"101. Nie ulega wątpliwości, że regulacja ta koresponduje $\mathrm{z}$ art. 68 Konstytucji RP normującym fundamentalną dla funkcjonowania całego systemu ochrony zdrowia

${ }^{99}$ Zob. S. Tyczka, I. Ponikowska, Człowiek, pogoda, klimat, Warszawa 1978, s. 77; A. Fiałkiewicz, M. Starzewska, Uzdrowiska dolnośląskie i ich okolice, Wrocław 1975, s. 12.

${ }^{100}$ Raport końcowy Zespotu do spraw opracowania koncepcji zmian w zakresie systemu lecznictwa uzdrowiskowego, Warszawa, 11 XII 2017, s. 16, dalej Raport.

${ }^{101}$ Lecznictwo uzdrowiskowe prowadzi się w zakładach lecznictwa uzdrowiskowego zlokalizowanych w strefie "A" ochrony uzdrowiskowej (art. 4 ust. 2 ustawy uzdrowiskowej). Zgodnie zaś z art. 2 pkt 6 ustawy uzdrowiskowej strefy ochrony uzdrowiskowej to części obszaru uzdrowiska określone w statucie uzdrowiska, wydzielone w celu ochrony czynników leczniczych i naturalnych surowców leczniczych, walorów środowiska i urządzeń uzdrowiskowych. 
zasadę, zgodnie z którą każdemu przysługuje prawo do ochrony zdrowia (ust. 1), a także z normą określającą w sposób ogólny kwestię dostępu do świadczeń opieki zdrowotnej finansowanej ze środków publicznych, który ma być równy niezależnie od sytuacji materialnej obywatela (ust. 2). Ustawodawca konstytucyjny (ustrojodawca) potraktował "ochronę zdrowia"102 wielokierunkowo i w taki sposób ustalił zadania dla właściwych władz publicznych, co oznacza, że obejmują one zapewnienie świadczeń opieki zdrowotnej, promocję zdrowego trybu życia, a także eliminowanie zagrożeń dla zdrowia. Ze wskazanych norm programowych ${ }^{103}$ wynika obowiązek władz publicznych stworzenia rozwiązań umożliwiających należytą realizację prawa do ochrony zdrowia ${ }^{104}$.

Sąd Najwyższy (SN), dokonując interpretacji art. 68 Konstytucji $\mathrm{RP}$, w wyroku z dnia 21 grudnia $2004 \mathrm{r} \cdot{ }^{105}$ stwierdzil, że treścią prawa do ochrony zdrowia jest realna możliwość korzystania z systemu ochrony zdrowia, funkcjonalne ukierunkowanie na zapobieganie chorobom, urazom i niepełnosprawności. Oznacza to, że: (1) system opieki zdrowotnej powinien działać, opierając się na środkach publicznych; (2) świadczenia finansowane ze środków publicznych mają być dostępne dla obywateli; (3) dostęp do świadczeń zdrowotnych finansowanych ze środków publicznych powinien być równy, co nie oznacza powszechnej dostępności do wszystkich znanych świadczeń opieki ${ }^{106}$.

Jak podkreśla M. Dercz, „norma konstytucyjna zawierająca prawo do ochrony zdrowia odwołuje się jednocześnie do pojęcia świadczeń opieki zdrowotnej"107. Pojęcie świadczenia zdrowotnego jest od lat powszechnie używane w wielu ustawach. Definicja zawarta w u.d.l. jest najistotniejsza, gdyż ma szczególne znaczenie systemowe. Określa zasady funkcjonowania podmiotów leczniczych jako instytucji prowadzących działalność leczniczą polegającą na udzielaniu świadczeń

102 Por. A. Wojtczak, Zdrowie publiczne wyzwaniem dla systemów zdrowia XXI wieku, Warszawa 2009, s. 19-20.

${ }^{103}$ D.E. Lach, Zasada równego dostępu do świadczeń opieki zdrowotnej, Warszawa 2011, s. $130-148$.

${ }^{104}$ M. Dercz, H. Izdebski, Organizacja ochrony zdrowia Rzeczypospolitej Polskiej w świetle obowiazującego ustawodawstwa, Warszawa-Poznań 2001, s. 10-18.

${ }^{105}$ Wyrok SN z dnia 21 XII 2004 r., sygn. I CK 320/04, LEX nr 369249.

106 G. Machulak, Komentarz do ustawy o świadczeniach opieki zdrowotnej finansowanych ze środków publicznych, Warszawa 2010, s. 46-50.

${ }^{107}$ M. Dercz, T. Rek, Ustawa o działalności leczniczej. Komentarz, Warszawa 2014, s. 39. 
zdrowotnych (art. 3 u.d.1. ${ }^{108}$. Istotę świadczeń zdrowotnych zakreślono w dwóch płaszczyznach: w sposób opisowy (abstrakcyjny) i przez wyliczenie podstawowych typów świadczeń. Określenie opisowe, bardziej uniwersalne, wskazuje dwa elementy: cel wykonywania świadczeń zdrowotnych oraz zawodowy charakter ich wykonywania ${ }^{109}$. Zgodnie $z$ art. 2 ust. 1 pkt 10 u.d.l. świadczeniem zdrowotnym są "działania służące zachowaniu, ratowaniu, przywracaniu lub poprawie zdrowia oraz inne działania medyczne wynikające z procesu leczenia lub przepisów odrębnych regulujących zasady ich wykonywania". W procesie udzielania świadczeń zdrowotnych nie zawsze konieczne jest poprawianie stanu zdrowia, ale konieczne jego: zachowanie, ratowanie i przywracanie, poprawianie zaś tylko wtedy, gdy są do tego odpowiednie możliwości i warunki medyczne. W przepisie tym nie zawarto wyliczenia podstawowych typów świadczeń zdrowotnych, wzorem art. 3 u.z.o.z. ${ }^{110}$ Definicję legalną tego pojęcia zawiera także art. 5 pkt 40 u.ś.o.z.: świadczenie zdrowotne to "działanie służące profilaktyce, zachowaniu, ratowaniu, przywracaniu lub poprawie zdrowia oraz inne działanie medyczne wynikające $z$ procesu leczenia lub przepisów odrębnych regulujących zasady ich udzielania". Obie definicje są zbliżone, ale ta z u.ś.o.z., w porównaniu $z$ definicją $w$ art. 2 ust. 1 pkt 10 u.d.l., stawia na pierwszym miejscu działanie służące profilaktyce, a brak tego elementu w u.d.l. powoduje, zdaniem M. Dercza ${ }^{111}$, że podmioty wykonujące działalność leczniczą nie mają formalnej możliwości wpisania takiej działalności do rejestrów działalności leczniczej i nie mają formalnoprawnych podstaw jej wykonywania. Świadczenia profilaktyczne w ramach świadczeń zdrowotnych w świetle u.ś.o.z. można wykonywać także w innej formie niż poprzez prowadzenie działalności leczniczej. Należy zatem zunifikować obydwie definicje. Właściwym rozumieniem pojęcia świadczenia zdrowotnego zajmował się również Naczelny Sąd Administracyjny (NSA) ${ }^{112}$.

${ }^{108}$ Mogą być one udzielane na zasadach określonych w odrębnych przepisach także przez osoby fizyczne wykonujące dany zawód medyczny, w ramach grupowej praktyki: lekarskiej bądź pielęgniarek lub położnych.

${ }_{109}$ Por. Z. Leoński, Komentarz do art. 1-19, s. 11-12.

${ }^{110}$ Pomimo że nie było to poprzez użycie sformułowania „W szczególności” wyliczenie wyczerpujące (czternaście typów świadczeń zdrowotnych), pozwalało się lepiej zorientować w rodzajach świadczeń zdrowotnych.

${ }_{111}$ M. Dercz, T. Rek, Ustawa o działalności..., 2014, s. 45.

112 Szerzej zob. uzasadnienie wyroku NSA z 27 VI 2006 r., sygn. II FSK 1005/05, LEX nr 243005. 


\subsection{Gmina uzdrowiskowa i uzdrowisko}

Bezwzględnym warunkiem prowadzenia lecznictwa uzdrowiskowego na danym obszarze jest obowiązek posiadania przez gminę jako podstawową jednostkę samorządu terytorialnego statusu gminy uzdrowiskowej, co oznacza gminę, której obszarowi lub jego części został nadany status uzdrowiska. Należy tu wskazać, że gmina uzdrowiskowa jest gminą o szczególnym ${ }^{113}$ charakterze prawnym i reżimie, co wynika z zachowania funkcji leczniczej uzdrowiska. Cechuje się ona odrębnościami, do których należą ich następujące rodzaje: ustrojowe (obowiązek powołania komisji uzdrowiskowej), zadaniowo-kompetencyjne (realizacja dodatkowych zadań własnych), finansowe (możliwość pobierania opłaty uzdrowiskowej), planistyczne (obowiązek utworzenia stref ochrony uzdrowiskowej).

W trybie określonym w ustawie uzdrowiskowej uzdrowisko to, według art. 2 pkt 3 tego aktu, obszar, na terenie którego prowadzone jest lecznictwo uzdrowiskowe, wydzielony w celu wykorzystania i ochrony znajdujących się na jego obszarze naturalnych surowców leczniczych, któremu został nadany status uzdrowiska. Zarówno z powyższych analiz, jak i przyjętej konstrukcji ustawowej definicji wynika, że uzdrowisko jest ograniczonym obszarem terytorium gminy, prowadzącym specyficzną działalność - lecznictwo uzdrowiskowe, które jest integralną częścią systemu zdrowia. Obecnie w Polsce wydzielono 45 uzdrowisk położonych na obszarze 42 gmin uzdrowiskowych, znajdujących się na terenie 13 województw ${ }^{114}$. Według Normy Polskiej ze względu na rodzaje warunków leczniczych uzdrowiska dzieli się ${ }^{115}$ na: klimatyczne, zdrojowiska, borowinowe, nadmorskie (thalassoterapeutyczne). Podział na te cztery rodzaje owocuje odmiennymi wymaganiami odnośnie do kształtowania przestrzeni tych założeń, wynikającymi z kierunków, profili leczniczych i ochrony naturalnych surowców leczniczych. Przy tym w literaturze podnosi się, że w rzeczywistości często funkcjonują założenia nie tylko jednego typu, i ze względu na kombinacje tworzyw leczniczych są to zdrojowiska: borowinowe, klimatyczne,

${ }^{113}$ Por. P. Jankowska, Szczególny charakter gmin uzdrowiskowych, w: Prawo i Administracja, t. 9, pod red. K. Wojtczak, Piła 2010.

${ }_{114}$ Zdrowie i ochrona zdrowia w 2017 r., Główny Urząd Statystyczny, Warszawa-Kraków 2018, s. 64, https://www.gov.pl/web/zdrowie-wykaz-uzdrowisk-wraz-z-kierunkami-leczniczymi (dostęp: 10 III 2020).

115 Polska Norma PN-71/Z-11000. 
klimatyczno-borowinowe, a także thalassoterapeutyczne czy klimatyczno-borowinowe ${ }^{116}$.

Z kolei zarówno według danych Ministerstwa Zdrowia ${ }^{117}$, jak i opracowanych przez Najwyższą Izbę Kontroli (NIK) ${ }^{118}$ - z uwzględnieniem liczby uzdrowisk oraz udziału procentowego w skali wszystkich 45 uzdrowisk - generalnie polskie uzdrowiska można podzielić, biorąc pod uwagę:

- położenie geograficzne: uzdrowiska nizinne położone do $200 \mathrm{~m}$ n.p.m. (17 uzdrowisk, co stanowi 38\%); uzdrowiska nadmorskie, położone w odległości nie większej niż $3 \mathrm{~km}$ od brzegu morza (6 uzdrowisk, 13\%); uzdrowiska podgórskie, położone od 200 do 400 m n.p.m. (14 uzdrowisk, 31\%); uzdrowiska górskie, położone od 400 do $800 \mathrm{~m}$ n.p.m. (8 uzdrowisk, 38\%).

- występujące naturalne surowce lecznicze: zdrojowiska - uzdrowiska posiadające wody lecznicze (33 uzdrowisk, 73\%); uzdrowiska borowinowe - zajmujące się leczeniem borowiną ( 5 uzdrowisk, $11 \%)$; uzdrowiska mieszane - posiadające wody lecznicze i borowinę (7 uzdrowisk, 16\%).

\subsection{Zakład lecznictwa uzdrowiskowego i urządzenia lecznictwa uzdrowiskowego}

Ze względu na to, że lecznictwo uzdrowiskowe w uzdrowiskach jest prowadzone w zakładach lecznictwa uzdrowiskowego, aktualnie pojęcie tego zakładu reguluje art. 2 pkt 10 ustawy uzdrowiskowej, zgodnie z którym jest to zakład leczniczy, w którym podmiot leczniczy wykonuje działalność leczniczą w rodzaju ambulatoryjne lub stacjonarne i całodobowe świadczenia zdrowotne w rozumieniu przepisów o działalności leczniczej ${ }^{119}$, działający na obszarze uzdrowiska, utworzony w celu udzielania świadczeń zdrowotnych z zakresu lecznictwa uzdrowiskowego albo rehabilitacji uzdrowiskowej, w ramach kierunków leczniczych i przeciwwskazań ustalonych dla danego uzdrowiska, w szczególności

${ }^{116}$ Zob. E. Węcłowicz-Bilska, Uzdrowiska polskie. Zagadnienia programowo-przestrzenne, Kraków 2008, s. 24.

117 http://mz.gov.pl/ (dostęp: 10 III 2020).

${ }_{118}$ Kontrola NIK, Spetnianie wymogów określonych dla uzdrowisk (P/16/091), Nr ewid. 179/2016/P/16/091/LSZ, LSZ.430.003.2016, s. 6.

119 Aktualnie według art. 2 ust. 1 pkt 14 u.d.l. zakład leczniczy oznacza zespół składników majątkowych, za pomocą którego podmiot leczniczy wykonuje określony rodzaj działalności leczniczej. 
wykorzystujących warunki naturalne uzdrowiska przy udzielaniu świadczeń zdrowotnych.

Oprócz zakładów lecznictwa uzdrowiskowego ważne znaczenie dla procesu leczenia uzdrowiskowego mają także urządzenia lecznictwa uzdrowiskowego. Zgodnie z art. 2 pkt 8 ustawy uzdrowiskowej są to urządzenia służące do leczniczego wykorzystania naturalnych surowców leczniczych oraz właściwości leczniczych klimatu.

\section{Typologia zakładów lecznictwa uzdrowiskowego i urządzeń lecznictwa uzdrowiskowego oraz warunki, jakim one powinny odpowiadać}

Zgodnie z art. 4 ust. $2 \mathrm{w}$ zw. $\mathrm{z}$ art. 5 ust. 1 ustawy uzdrowiskowej w uzdrowiskach lecznictwo uzdrowiskowe jest prowadzone: (1) w zakładach lecznictwa uzdrowiskowego zlokalizowanych w strefie "A" ochrony uzdrowiskowej; (2) przy wykorzystaniu urządzeń lecznictwa uzdrowiskowego.

Ustawa uzdrowiskowa w art. 6 określa zamknięty katalog zakładów lecznictwa uzdrowiskowego, do którego zalicza: (1) szpitale uzdrowiskowe; (2) sanatoria uzdrowiskowe; (3) szpitale uzdrowiskowe dla dzieci i sanatoria uzdrowiskowe dla dzieci; (4) przychodnie uzdrowiskowe; (5) zakłady przyrodolecznicze; (6) szpitale i sanatoria w urządzonych podziemnych wyrobiskach górniczych. Podstawą tak przyjętego podziału jest ${ }^{120}$ : (1) zróżnicowana intensywność środków oddziaływania leczniczego w poszczególnych zakładach lecznictwa uzdrowiskowego; (2) zróżnicowany reżim wewnętrzny; (3) odmienne zasady kwalifikowania do leczenia uzdrowiskowego.

Jak wynika z danych Głównego Urzędu Statystycznego (GUS) ${ }^{121}$, w końcu 2018 r. funkcjonowało 49 szpitali uzdrowiskowych (w tym 6 dla dzieci), 192 sanatoria uzdrowiskowe (w tym 3 dla dzieci i jedno sanatorium w urządzonym podziemnym wyrobisku górniczym), 11 przychodni i 19 zakładów przyrodoleczniczych obsługujących kompleksy uzdrowiskowe. Łącznie 271 zakładów w ciągu roku przyjęło 838,5 tys. pacjentów, w tym 759,8 tys. leczonych stacjonarnie.

Tym, co łączy te wszystkie typy zakładów, jest sformułowanie: „zapewnienie pacjentowi”. Oznacza to, że przyjęta w u.p.p. jednolita

\footnotetext{
${ }^{120}$ Z. Kruczek, A. Weseli, Uzdrowiska karpackie, Kraków 1987, s. 30.

${ }^{121}$ GUS z 2018 r. - notka, s. 1.
} 
definicja ${ }^{122}$ tej szczególnej kategorii osób znajduje zastosowanie w ustawie uzdrowiskowej w stosunku do korzystających ze świadczeń opieki zdrowotnej z zakresu lecznictwa uzdrowiskowego. Potwierdza to art. 15 ustawy uzdrowiskowej, który stanowi, że w sprawach w niej nieuregulowanych do zakładów lecznictwa uzdrowiskowego mają zastosowanie przepisy ustawy o prawach pacjenta. W regulacji tej znajduje się też odesłanie do ustawy o działalności leczniczej, co oznacza, że wszystkie rodzaje zakładów lecznictwa uzdrowiskowego spełniają kryteria podmiotu prowadzącego działalność lecznicząa ${ }^{123}$.

Tym, co odróżnia poszczególne rodzaje zakładów, są zadania przez nie wykonywane. Przy czym można przyjąć, że „[p]odstawowe zadania zakładów lecznictwa uzdrowiskowego to leczenie, rehabilitacja, prewencja pierwotna i wtórna oraz edukacja zdrowotna, a wskazania obejmują także choroby przewlekłe, w szczególności choroby cywilizacyjne $^{\prime \prime 24}$. Z analizy art. 8-12 ustawy uzdrowiskowej wynika, że ze względu na to, iż szpital uzdrowiskowy przeznaczony jest dla osób, których stan zdrowia wymaga udzielania całodobowych świadczeń zdrowotnych, podlega on szczególnemu reżimowi. Przejawia się to w obowiązku realizowania szerokiego zakresu usług (nie tylko świadczeń zdrowotnych), a także w szczególnych prawach (i obowiązkach) przebywających w szpitalach pacjentów ${ }^{125}$. Warto dodać, że szpital zapewnia przyjętym pacjentom przede wszystkim świadczenia zdrowotne, ale - co oczywiste - nie wszystkie. Zindywidualizowany szpital nie udziela wszelkich świadczeń zdrowotnych, lecz tylko te, których rodzaje i zakres określa statut. Jak słusznie zauważa K. Wojtczak, świadczenia te powinny odpowiadać wymaganiom wiedzy medycznej ${ }^{126}$. Obowiązkiem każdego szpitala jest ponadto zapewnienie przyjętemu pacjentowi pomieszczenia (tzw. zakwaterowania) i wyżywienia odpowiedniego do stanu zdrowia. Usługi z tego zakresu często nazywa się "hotelarskimi”. Element ten wyróżnia szpitale wśród innych tzw. otwartych zakładów opieki zdrowotnej udzielających świadczeń zdrowotnych w warunkach ambulatoryjnych. Należy zauważyć, że przepis nie rozstrzyga kwestii

${ }^{122}$ Zob. D. Karkowska, Ustawa o prawach pacjenta..., s. 76.

${ }^{123}$ Zob. art. 6 art. 6 u.d.l., w którym ustawodawca określił formy organizacyjno-prawne podmiotu prowadzącego działalność leczniczą, dokonując ich podziału na publiczne i niepubliczne - będące i niebędące przedsiębiorcami.

${ }^{124}$ Raport, s. 19.

${ }_{125}$ M. Dercz, T. Rek, Ustawa o działalności leczniczej. Komentarz, Warszawa 2011, s. 136 i n.

${ }^{126}$ K. Wojtczak, Komentarz do art. 20-26, w: Z. Leoński, K. Wojtczak, Komentarz do ustawy..., s. 36 . 
odpłatności bądź bezpłatności usług realizowanych przez szpital. Jak zauważa K. Wojtczak, „oznacza jedynie obowiązek zagwarantowania przez szpitale [...] ich spełnienia w stosunku do każdej osoby już przyjętej [...] do szpitala"127. Wymienione w przepisie cechy (obowiązki) szpitala stanowią w pewnym sensie jego charakterystykę, składając się na jego definicję. Pacjent nie może jednak na tej podstawie żądać zapewnienia mu nieodpłatnego pobytu w szpitalu ${ }^{128}$. W kontekście użytego przez ustawodawcę uzdrowiskowego pojęcia "szpital uzdrowiskowy" rysuje się problem braku jego legalnej definicji, a w konsekwencji rodzi się też pytanie, czy "szpital uzdrowiskowy" jest "szpitalem” $\mathrm{w}$ rozumieniu art. 2 ust. 1 pkt 9 u.d.l., przez który rozumie się zakład leczniczy, w którym podmiot leczniczy wykonuje działalność leczniczą w rodzaju świadczenia szpitalne. Mankamenty te potęguje zagadnienie pobierania opłaty uzdrowiskowej „od osób przebywających w szpitalach" uregulowanej w przepisach odrębnych ${ }^{129}$.

Z chwilą przyjęcia do zakładu lecznictwa uzdrowiskowego pacjent poddaje się dobrowolnie prawu zakładowemu i jego sytuacja prawna kształtowana jest wówczas przez porządek prawny oraz normy prawa wewnętrznego. Osoba, która stała się pacjentem (użytkownikiem zakładu lecznictwa uzdrowiskowego), będąc od tej chwili podporządkowana organom zakładu i jego pracownikom, stała się adresatem norm wydawanych właśnie przez te organy. Stosunki administracyjne tego typu Z. Leoński określa stosunkami występującymi w układach zależności organizacyjnej ${ }^{130}$. Przepisami prawa zakładowego, które kształtują sytuację pacjenta, są statut i regulaminy zakładowe. Zakres uzdrowiskowego władztwa zakładowego wynika z charakteru zakładu lecznictwa uzdrowiskowego, jego celów i zadań.

Specjalizację poszczególnych typów zakładów lecznictwa uzdrowiskowego określa zwykle profil leczniczy uzdrowiska. Specjalizacja taka pociąga za sobą konieczność lokalizowania gabinetów do badań

${ }^{127}$ Ibidem, s. 37.

${ }_{128}$ Zob. M. Dercz, T. Rek, Ustawa o zakładach..., s. 154.

129 Zob. art. 17 ust. 1a Ustawy z dnia 12 I 1991 r. o podatkach i opłatach lokalnych (tekst jedn. Dz.U. 2019, poz. 1170 ze zm., dalej „u.p.o.l.”), zgodnie z którym opłatę uzdrowiskową pobiera się od osób fizycznych przebywających dłużej niż dobę w celach zdrowotnych, turystycznych, wypoczynkowych lub szkoleniowych w miejscowościach znajdujących się na obszarach, którym nadano status uzdrowiska na zasadach określonych w ustawie uzdrowiskowej - za każdą rozpoczętą dobę pobytu. Z kolei art. 17 ust. 2 u.p.o.l. określa sytuacje, w których nie pobiera się opłaty uzdrowiskowej.

${ }^{130}$ Z. Leoński, Zarys prawa administracyjnego, Warszawa 2000, s. 28. 
i zabiegów specjalistycznych, wyposażenia ich w specjalną aparaturę, dobór kwalifikowanych $\mathrm{kadr}^{131}$. W odniesieniu do uzdrowisk aktualnie przyjęto siedemnaście głównych kierunków leczniczych charakteryzujących w sposób ogólny możliwości terapeutyczne poszczególnych miejscowości ${ }^{132}$. Rodzaj i zakres udzielanych świadczeń opieki zdrowotnej wynikających z dostępnych naturalnych surowców leczniczych i warunków klimatycznych określa statut zakładu lecznictwa uzdrowiskowego ${ }^{133}$.

Zakłady lecznictwa uzdrowiskowego przeznaczone do leczenia chorób zawodowych powinny być lokalizowane w uzdrowiskach o odpowiednim profilu leczniczym. W ramach określonych kierunków leczniczych uzdrowisk należy w szczególności uwzględniać leczenie uzdrowiskowe osób, u których wystąpiły choroby zawodowe (art. 13 ust. 2 ustawy uzdrowiskowej). Dotyczy to obecnie osób zatrudnionych przy produkcji wyrobów zawierających azbest. W tym zakresie obowiązuje Rozporządzenie Ministra Zdrowia z dnia 9 sierpnia 2004 r. w sprawie leczenia uzdrowiskowego osób zatrudnionych przy produkcji wyrobów zawierających azbest ${ }^{134}$. Jeżeli chodzi o urządzenia lecznictwa uzdrowiskowego, to ustawodawca w art. 5 ust. 1 ustawy uzdrowiskowej tylko je wymienia, i należą do nich: pijalnie uzdrowiskowe, tężnie, parki, ścieżki ruchowe, urządzone odcinki wybrzeża morskiego, lecznicze i rehabilitacyjne baseny uzdrowiskowe, urządzone podziemne wyrobiska górnicze. Według zaś ust. 2 ustawy urządzenia te są udostępniane użytkownikom zgodnie $\mathrm{z}$ regulaminem korzystania ${ }^{135} \mathrm{z}$ tych urządzeń, sporządzonym przez podmiot posiadający te urządzenia.

${ }^{131}$ Zob. Z. Kruczek, A. Weseli, op. cit., s. 22.

132 Zgodnie z art. 13 ust. 1 ustawy uzdrowiskowej ustala się następujące kierunki lecznicze uzdrowisk: (1) choroby ortopedyczno-urazowe; (2) choroby układu nerwowego; (3) choroby reumatologiczne; (4) choroby kardiologiczne i nadciśnienie; (5) choroby naczyń obwodowych; (6) choroby górnych dróg oddechowych; (7) choroby dolnych dróg oddechowych; (8) choroby układu trawienia; (9) cukrzyca; (10) otyłość; (11) choroby endokrynologiczne; (12) osteoporoza; (13) choroby skóry; (14) choroby kobiece; (15) choroby nerek i dróg moczowych; (16) choroby krwi i układu krwionośnego; (17) choroby oka i przydatków oka.

${ }^{133}$ Zob. art. 13 ust. 3 ustawy uzdrowiskowej. Por. np. uchwałę Nr V/76/2019 Rady Miasta Sopotu z dnia 28 III 2019 r. w sprawie nadania statutu Samodzielnemu Publicznemu Zakładowi Opieki Zdrowotnej „Uzdrowisko Sopot” w Sopocie (Dz.Urz. Woj. Pomorskiego, poz. 2429).

${ }^{134}$ Dz.U. Nr 185, poz. 1920 ze zm.

${ }^{135}$ Na przykład uchwała Nr XVI/79/2011 Rady Miasta Świeradów-Zdrój z dnia 26 X 2011 r. w sprawie ustanowienia regulaminu korzystania z kompleksu parków uzdrowiskowych na terenie Gminy Miejskiej Świeradów-Zdrój (Dz.Urz. Woj. Dolnośląskiego, $\mathrm{Nr} 265$, poz. 5056). Regulamin ten to akt prawa miejscowego wydany w formie uchwały 
Zgodnie z art. 5 ust. 3 ustawy uzdrowiskowej Minister Zdrowia określił, w drodze rozporządzenia, wymagania eksploatacyjne, funkcjonalne i techniczne, jakim powinny odpowiadać urządzenia lecznictwa uzdrowiskowego, kierując się wymaganiami określonymi dla tych obiektów oraz standardami przyjętymi w celu zapewnienia efektywności zabiegów i warunków sanitarnohigienicznych oraz uwzględniając ochronę dóbr kultury, a także zagrożenia geologiczne i górnicze w odniesieniu do wyrobisk górniczych. W tej materii obecnie obowiązuje Rozporządzenie Ministra Zdrowia z dnia 2 kwietnia 2012 r. w sprawie określenia wymagań, jakim powinny odpowiadać zakłady i urządzenia lecznictwa uzdrowiskowego ${ }^{136}$. Warto tu podać, że ten akt wykonawczy, ustalając wymagania dla poszczególnych typów zakładów i urządzeń, w ramach których prowadzone jest lecznictwo uzdrowiskowe, uwzględnia ich typologię, jaka wynika z ustawy uzdrowiskowej.

Według art. 41 ust. 2a ustawy uzdrowiskowej wykaz zakładów lecznictwa uzdrowiskowego, urządzeń lecznictwa uzdrowiskowego i kierunków leczniczych ustalonych przez Ministra Zdrowia zawiera statut uzdrowiska będący aktem prawa miejscowego ${ }^{137}$.

\section{Kierowanie i kwalifikowanie pacjentów do zakładów lecznictwa uzdrowiskowego}

\subsection{Podstawa przyjęcia do zakładu lecznictwa uzdrowiskowego $\mathrm{i}$ jej wpływ na status prawny pacjenta tego zakładu}

Zgodnie z art. 14 ustawy uzdrowiskowej świadczenia zdrowotne w zakładach lecznictwa uzdrowiskowego są udzielane na podstawie wystawionych przez lekarza:

przez radę gminy w zakresie zasad i trybu korzystania z gminnych obiektów urządzeń użyteczności publicznej.

${ }^{136}$ Tekst jedn. Dz.U. 2018, poz. 496 ze zm. Stosownie do $§ 1$ rozporządzenie szczegółowo określa: (1) wymagania, jakim powinny odpowiadać zakłady lecznictwa uzdrowiskowego; (2) wymagania eksploatacyjne, funkcjonalne i techniczne, jakim powinny odpowiadać urządzenia lecznictwa uzdrowiskowego.

${ }^{137}$ Na przykład uchwała Nr XXXVIII/375/2017 z dnia 28 VI 2017 r. w sprawie uchwalenia Statutu Uzdrowiska Połczyn-Zdrój (Dz.Urz. Woj. Zachodniopomor., poz. 3312). Por. wyrok NSA z 19 V 2015 r., sygn. II OSK 2528/13, http://orzeczenia.nsa.gov.pl/doc/ D26B355D48 (dostęp: 10 III 2020). 
- skierowania na leczenie uzdrowiskowe albo rehabilitację uzdrowiskową albo

- zaświadczenia o braku przeciwwskazań do korzystania z danego rodzaju świadczeń zdrowotnych w danym uzdrowisku.

Przepis ten oznacza, że podstawą przyjęcia do zakładu lecznictwa uzdrowiskowego jest nie tylko skierowanie na leczenie, lecz zaświadczenie o braku przeciwwskazań do korzystania z danego rodzaju świadczeń zdrowotnych (tzw. pobyty komercyjne). Jak podnosi się w piśmiennictwie ${ }^{138}$, nie ma tutaj znaczenia, czy dana osoba przebywa w przedmiotowo określonych zakładach na podstawie skierowania NFZ czy za pełną odpłatnością. Ważne jest jedynie to, czy przebywa w owym zakładzie i czy ten pobyt jest świadczeniem zdrowotnym.

Z kolei sądy administracyjne ${ }^{139}$, uwzględniając te dwie formy przyjęcia na leczenie uzdrowiskowe, w powiązaniu $\mathrm{z}$ analizą zakresu zwolnienia z opłaty uzdrowiskowej, wypowiedziały się także odnośnie do zrównania statusu pacjenta na podstawie skierowania lekarskiego i na zasadzie tzw. "pobytów komercyjnych". Pacjenci samodzielnie opłacający (finansujący) pobyt w szpitalach uzdrowiskowych należących do uzdrowisk są zatem traktowani tak samo jak ci kierowani na leczenie przez NFZ. Żadna z ustaw regulujących zasady funkcjonowania szpitali uzdrowiskowych ani u.p.o.l. nie daje podstawy do takiego rozróżnienia między pacjentami obu kategorii. Potwierdził to także NSA w wyroku z 30 sierpnia 2011 r., który zważył, że „nieuzasadnione jest różnicowanie pacjentów $[\ldots] \mathrm{w}$ zależności od tego, czy korzystają z leczenia na zasadach określonych w przepisach u.ś.o.z., czy jako pacjenci, którzy nie uzyskali skierowania na podstawie tych przepisów (odpłatnie)"140. Stanowisko to spotkało się z dezaprobatą niektórych organów podatkowych w gminach uzdrowiskowych, zdaniem których zasada przyjęcia do szpitala uzdrowiskowego jest skierowanie na leczenie uzdrowiskowe i tylko skierowanie lekarskie jest podstawą przyjęcia pacjenta,

${ }^{138}$ M. Cienkowski, T. Wołowiec, Opłata miejscowa i uzdrowiskowa jako daniny pobierane w miejscowościach turystycznych i uzdrowiskowych, "Zeszyty Naukowe Uczelni Warszawskiej im. Marii Skłodowskiej-Curie" 2014, nr 4(45), s. 229-249. Zob. także T. Wołowiec, Pobyt w szpitalu uzdrowiskowym a obowiazek poboru opłaty uzdrowiskowej, "Przegląd Prawa Publicznego" 2016, nr 1, s. 68.

${ }^{139}$ Na przykład wyrok WSA we Wrocławiu z 24 XI 2009 r., sygn. I SA/Wr 1439/09, http://orzeczenia.nsa.gov.pl/doc/14FB5F5F01 (dostęp: 10 III 2020); wyrok NSA Ośrodek Zamiejscowy w Gdańsku z 25 VIII 1994 r., sygn. SA/Gd 858/94, Legalis nr 38759.

${ }^{140}$ Wyrok NSA z 30 VIII 2011 r., sygn. II FSK 408/10, LEX nr 896063. 
a pozostałe osoby, przebywające w szpitalach na turnusach uzdrowiskowych czy na tzw. pobytach komercyjnych, są obowiązane do uiszczenia tej opłaty.

\section{2. Świadczeniobiorca a pacjent}

Artykuł 14 ustawy uzdrowiskowej koresponduje z art. 33 ust. 1 i 2 zd. 1 u.ś.o.z., które stanowią: leczenie uzdrowiskowe albo rehabilitacja uzdrowiskowa przysługuje świadczeniobiorcy - są to dwie kategorie osób uprawnionych: ubezpieczeni ${ }^{141}$ i osoby inne niż ubezpieczeni ${ }^{142}$, spełniające kryteria określone przepisami ${ }^{143}$ - na podstawie skierowania wystawionego przez lekarza ubezpieczenia zdrowotnego. Skierowanie to wymaga potwierdzenia przez oddział wojewódzki NFZ właściwy ze względu na miejsce zamieszkania świadczeniobiorcy, a jeżeli nie można ustalić miejsca jego zamieszkania - oddział wojewódzki NFZ właściwy dla siedziby świadczeniodawcy, który je wystawił.

Zasygnalizowania w tym miejscu wymaga, że nawiązanie stosunku (zakładowego) następuje w drodze administracyjnej, a udzielanie świadczeń zdrowotnych na podstawie skierowań. Ustawodawca w u.ś.o.z. nie definiuje pojęć: "skierowanie” czy "skierowanie lekarza ubezpieczenia zdrowotnego lub felczera ubezpieczenia zdrowotnego", lecz określa, w przypadku jakich świadczeń zdrowotnych finansowanych ze środków publicznych wymagane jest uprzednie posiadanie przez pacjenta dokumentu potwierdzającego potrzebę uzyskania określonego świadczenia uprawniającego do korzystania z leczenia uzdrowiskowego albo rehabilitacji.

Jak podnosi się $\mathrm{w}$ doktrynie ${ }^{144}$, treść powyższej regulacji (art. 33 u.ś.o.z.) może zatem statuować ogólne prawo pacjenta do mającego ustawowy status świadczeniobiorcy do świadczeń zdrowotnych finansowanych ze środków publicznych. Podmiotem uprawnionym do

${ }^{141}$ Do korzystania ze świadczeń opieki zdrowotnej na zasadach określonych w u.ś.o.z. mają prawo: osoby objęte obowiązkowym i dobrowolnym ubezpieczeniem zdrowotnym, zwane "ubezpieczonymi" (art. 2 ust. 1 pkt 1).

${ }^{142}$ Osoby inne niż ubezpieczeni zwane są „świadczeniobiorcami” - zob. art. 2 ust. 1 pkt 2-4 u.ś.o.z.

${ }^{143}$ Przepisy odrębne regulują tu jednak pewien wyjątek. Zob. art. 73 Ustawy z dnia 13 VI 2003 r. o udzielaniu cudzoziemcom ochrony na terytorium Rzeczypospolitej Polskiej (tekst jedn. Dz.U. 2019, poz. 1666).

${ }^{144}$ M. Paszkowska, Uzdrowiska w systemie ochrony zdrowia, Warszawa 2017, s. 215-217. 
realizacji tego prawa - tj. korzystającym ze świadczeń zdrowotnych z zakresu lecznictwa uzdrowiskowego - nie jest każdy pacjent, lecz tylko świadczeniobiorca $\mathrm{w}$ systemie publicznego ubezpieczenia zdrowotnego, czyli podmiot określony w art. 2 u.ś.o.z. Innymi słowy w dużym uproszczeniu świadczeniobiorcą są ubezpieczeni (obligatoryjnie i dobrowolnie), obywatele polscy do 18. roku życia, kobiety w okresie ciąży, porodu lub połogu posiadające miejsce zamieszkania na terytorium RP i cudzoziemcy w ściśle określonych przypadkach związanych $z$ ich statusem. W ślad za M. Paszkowską ${ }^{145}$ należy zatem przyjąć, że "[ś]wiadczeniobiorcy w rozumieniu normatywnym to w praktyce pacjenci. Jednakże nie są to pojęcia tożsame. Bowiem pojęcie «pacjent» jest pojęciem szerszym niż świadczeniobiorca czy też ubezpieczony. Pacjent to generalnie każda osoba korzystająca ze świadczeń zdrowotnych".

\subsection{Tryb (procedura) kierowania na leczenie uzdrowiskowe}

Ogólny tryb kierowania na leczenie uzdrowiskowe albo rehabilitację uzdrowiskową reguluje przytoczony już art. 33 u.ś.o.z. Na podstawie delegacji z ust. 5 tego aktu Minister Zdrowia wydał Rozporządzenie z dnia 7 lipca 2011 r. w sprawie kierowania na leczenie uzdrowiskowe albo rehabilitację uzdrowiskową ${ }^{146}$. Rozporządzenie określa sposób wystawiania skierowania ${ }^{147}$ na leczenie uzdrowiskowe albo rehabilitację uzdrowiskową przez lekarza ubezpieczenia zdrowotnego, tryb potwierdzania i wzór tego skierowania ( $\$ 1)$. Obecnie ${ }^{148}$ według zmienionego $\S 2$ ust. 1 rozporządzenia lekarz ubezpieczenia zdrowotnego wystawia skierowanie na leczenie uzdrowiskowe albo rehabilitację uzdrowiskowa, zwane dalej „skierowaniem”, biorąc pod uwagę: (1) wskazania i przeciwwskazania do leczenia uzdrowiskowego albo rehabilitacji uzdrowiskowej; (2) w przypadku dorosłych: (a) okres, jaki upłynął od dnia zakończenia przez świadczeniobiorcę ostatniego leczenia uzdrowiskowego albo rehabilitacji uzdrowiskowej - nie wcześniej niż przed upływem 12 miesięcy od tej daty, (b) zalecaną częstotliwość korzystania

${ }^{145}$ Ibidem, s. 217.

${ }^{146}$ Dz.U. Nr 142, poz. 835 ze zm., dalej „rozporządzenie”.

${ }^{147}$ Zgodnie z $\& 3$ rozporządzenia obowiązujący wzór skierowania określa załącznik do rozporządzenia.

148 Rozporządzenie Ministra Zdrowia z dnia 4 VI 2019 r. zmieniające rozporządzenie w sprawie kierowania na leczenie uzdrowiskowe albo rehabilitację uzdrowiskową (Dz.U. poz. 1136), dalej "rozporządzenie zmieniające”. 
z leczenia uzdrowiskowego albo rehabilitacji uzdrowiskowej, nie częściej niż raz na 18 miesięcy ${ }^{149}$. Odnośnie do tej regulacji Prezydium Naczelnej Rady Lekarskiej, już po zapoznaniu się z projektem analizowanego rozporządzenia zmieniającego, zgłosiło, że "wątpliwości budzi zmiana zaproponowana w $\S 2$ ust. 1 pkt 2 rozporządzenia, zgodnie z którą lekarz będzie zobowiązany do stwierdzania, kiedy pacjent po raz ostatni korzystał z leczenia uzdrowiskowego lub rehabilitacji uzdrowiskowej. W ocenie Prezydium Naczelnej Rady Lekarskiej pacjent powinien składać oświadczenie w przedmiotowym zakresie lub mieć obowiązek dostarczenia karty z leczenia uzdrowiskowego"150.

Kolejno lekarz wystawiający skierowanie jest obowiązany do prawidłowego i czytelnego wypełnienia skierowania ( $\$ 2$ ust. 5 rozporządzenia). Aktualnie ${ }^{151}$ skierowanie, w terminie 30 dni od dnia jego wystawienia przez lekarza, pod rygorem utraty ważności skierowania, przesyła się do oddziału wojewódzkiego NFZ w zamkniętej kopercie opatrzonej napisem "skierowanie na leczenie uzdrowiskowe" albo „skierowanie na rehabilitację uzdrowiskową". Skierowanie może być przesłane przez świadczeniobiorcę wskazanego w skierowaniu ( 22 ust. 6 rozporządzenia) $)^{152}$.

Po otrzymaniu skierowania przez oddział wojewódzki NFZ komórka organizacyjna właściwa w zakresie lecznictwa uzdrowiskowego i rehabilitacji uzdrowiskowej dokonuje jego rejestracji poprzez wpis na listę skierowań oraz oznacza skierowanie numerem wpisu, pod którym skierowanie zostało wpisane na listę skierowań. Po dokonaniu rejestracji skierowania lekarz specjalista w dziedzinie balneologii i medycyny fizykalnej lub rehabilitacji medycznej zatrudniony w komórce organizacyjnej dokonuje aprobaty skierowania pod względem celowości leczenia uzdrowiskowego albo rehabilitacji uzdrowiskowej. Lekarz specjalista może zażądać od lekarza ubezpieczenia zdrowotnego,

${ }^{149}$ Zgodnie z $\S 2$ ust. 2 rozporządzenia przepisu tego nie stosuje się do leczenia uzdrowiskowego w szpitalu uzdrowiskowym i leczenia uzdrowiskowego w formie rehabilitacji uzdrowiskowej w szpitalu uzdrowiskowym oraz w uzdrowiskowym leczeniu ambulatoryjnym. Zob. także art. 19 ust. 3 ustawy uzdrowiskowej.

${ }^{150}$ Stanowisko Nr 74/18/P-VIII Prezydium Naczelnej Rady Lekarskiej z dnia 23 XI 2018 r. w sprawie projektu rozporządzenia Ministra Zdrowia zmieniającego rozporządzenie w sprawie kierowania na leczenie uzdrowiskowe albo rehabilitację uzdrowiskową - pkt 1, dalej „Stanowisko Prezydium NRL”.

${ }_{151}$ Zmiana wynika z $\S 1$ pkt 1 lit. c rozporządzenia zmieniającego.

${ }^{152}$ A. Iwiński, Zmiany w leczeniu w uzdrowiskach, "Gazeta dla Pacjenta". Dwumiesięcznik Porozumienia Pracodawców Ochrony Zdrowia, Rok IX, 2019, nr 2, s. 20-21. 
który wystawił skierowanie, dostarczenia w wyznaczonym terminie dokumentacji medycznej niezbędnej do ustalenia rodzaju i zakresu leczenia uzdrowiskowego albo rehabilitacji uzdrowiskowej, uzupełnienia lub aktualizacji tej dokumentacji oraz przeprowadzenia dodatkowych badań ( $§ 3$ ust. 1-3).

Oceny przesłanek uznania zwrotu potwierdzonego skierowania na leczenie uzdrowiskowe za nieuzasadniony podjął się WSA w Warszawie w wyroku z 13 lutego 2014 r. ${ }^{153}$ Zdaniem sądu zwrot potwierdzonego skierowania przez świadczeniobiorcę traktowany jest jako złożenie nowego skierowania, które przekazywane jest do ponownej rejestracji i oceny celowości leczenia zgodnie z art. 33 ust. 2 u.ś.o.z. (w zw. z § 3 ust. 2 analizowanego rozporządzenia Ministra Zdrowia). Czynność uznania zwrotu skierowania za nieuzasadnioną ingeruje w przyznane świadczeniobiorcy prawo do świadczenia zdrowotnego, prowadząc $\mathrm{w}$ istocie do zanegowania celowości samego skierowania na leczenie. Powtórnie otwiera zasadniczy etap realizacji uprawnienia do świadczenia opieki zdrowotnej, o którym mowa w art. 15 ust. 2 pkt $8 \mathrm{w}$ zw. $z$ art. 33 ust. 1 u.ś.o.z., który następuje po etapie wystawienia skierowania na leczenie przez lekarza ubezpieczenia zdrowotnego, a mianowicie etap jego weryfikacji, który wieńczony jest jego potwierdzeniem albo odmową aprobaty przez oddział wojewódzki NFZ. Ponadto czynność uznania zwrotu skierowania na leczenie uzdrowiskowe za nieuzasadnione jest podejmowana przez organ administracji. Charakteryzuje się cechą jednostronności, ma charakter indywidualny w tym sensie, że jej przedmiotem jest konkretne uprawnienie konkretnego świadczeniobiorcy do konkretnego świadczenia zdrowotnego z zakresu lecznictwa uzdrowiskowego (art. 33 u.ś.o.z.). Czynność tę należy więc zakwalifikować jako czynność określoną w art. 3 § 2 pkt 4 Ustawy z dnia 30 sierpnia 2002 r. Prawo o postępowaniu przed sądami administracyjnymi ${ }^{154}$. Skarga dotycząca uznania zwrotu skierowania za nieuzasadnione nie może ulec odrzuceniu na podstawie art. $58 \S 1$ pkt 1 p.p.s.a., dotyczy bowiem sprawy z zakresu administracji publicznej, w której podejmowana jest czynność objęta właściwością sądu administracyjnego.

Rozporządzenie w $\S 4$ ust. 1-8 reguluje procedurę potwierdzania skierowania przez oddział wojewódzki NFZ. Następuje to w sytuacji, gdy: (1) lekarz specjalista aprobował celowość skierowania;

${ }^{153}$ Wyrok WSA w Warszawie z 13 II 2014 r., sygn. VI SA/Wa 2367/13, http://orzeczenia.nsa.gov.pl/doc/DAC1C6260F (dostęp: 10 III 2020).

${ }^{154}$ Obecnie tekst jedn. Dz.U. 2019, poz. 2325 ze zm., dalej „p.p.s.a.”. 
(2) w odpowiednich zakładach lecznictwa uzdrowiskowego albo rehabilitacji uzdrowiskowej są wolne miejsca, przewidziane w umowach z tymi zakładami.

Należy tu wskazać, że rozporządzeniem zmieniającym ${ }^{155}$ wprowadzono zmianę wzoru skierowania poprzez usunięcie części, w której to lekarz ubezpieczenia zdrowotnego, wystawiający skierowanie, mógł określić miejsce i rodzaj leczenia uzdrowiskowego albo rehabilitacji uzdrowiskowej. Tym bardziej uwagę zwraca stanowisko Prezydium NRL, w ocenie którego "należy pozostawić lekarzowi ubezpieczenia zdrowotnego możliwość wpisania na skierowaniu miejsca i rodzaju leczenia uzdrowiskowego. Lekarz ubezpieczenia zdrowotnego posiada więcej informacji o swoim pacjencie, którymi nie dysponuje lekarz NFZ, np. o złej tolerancji pobytu pacjenta w konkretnym miejscu leczenia"156. Obecnie, potwierdzając skierowanie, oddział wojewódzki NFZ określa: rodzaj leczenia uzdrowiskowego albo rehabilitacji uzdrowiskowej oraz ich tryb; odpowiedni zakład lecznictwa uzdrowiskowego albo rehabilitacji uzdrowiskowej; datę rozpoczęcia leczenia albo rehabilitacji uzdrowiskowej; w przypadku leczenia uzdrowiskowego w warunkach stacjonarnych - czas trwania; okres leczenia, w przypadku leczenia uzdrowiskowego $\mathrm{w}$ warunkach ambulatoryjnych albo rehabilitacji uzdrowiskowej. W kontekście $\S 4$ ust. 2 badanego rozporządzenia, NSA w wyroku z 23 stycznia 2018 r. ${ }^{157}$ zważył, że w ustawie uzdrowiskowej oraz u.ś.o.z. i w przepisach wykonawczych nie ma podstaw prawnych do domagania się przez świadczeniobiorcę skierowania na leczenie w terminie i w miejscu przez niego wnioskowanym. Sąd dodał, że zarówno aprobata celowości skierowania, jak i ustalenie warunków leczenia sanatoryjnego należy do organu. Przepis ten był także przedmiotem kontroli Trybunału Konstytucyjnego (TK), który w wyroku z 26 kwietnia 2016 r. ${ }^{158}$ orzekł, że $\S 4$ ust. 2 rozporządzenia Ministra

${ }^{155}$ Zob. $\S 1$ pkt 4 rozporządzenia zmieniającego (Dz.U. 2019, poz. 1136), zgodnie z którym załącznik (wzór skierowania na leczenie uzdrowiskowe/rehabilitację uzdrowiskową) do rozporządzenia otrzymuje brzmienie określone w załączniku do niniejszego rozporządzenia.

${ }^{156}$ Zob. Stanowisko Prezydium NLR - pkt 2.

157 Wyrok NSA z 23 I 2018 r., sygn. II GSK 4944/16, http://orzeczenia.nsa.gov.pl/ doc/DAC1C6260F (dostęp: 10 III 2020).

${ }^{158}$ Wyrok TK z 26 IV 2016 r., sygn. TK U 1/15, Dz.U. 2016, poz. 1236. Ponadto TK podniósł, że $\S 5$ ust. 3 rozporządzenia powołanego w punkcie 1 (czyli Rozporządzenia Ministra Zdrowia z dnia 7 VII 2011 r. w sprawie kierowania na leczenie uzdrowiskowe albo rehabilitację uzdrowiskową) jest zgodny z art. 78 zd. 2 i art. 31 ust. 3 Konstytucji RP. 
Zdrowia jest zgodny z art. 33 ust. 5 pkt 2 u.ś.o.z. oraz z art. 92 ust. 1 zd. 1 i art. 68 ust. 2 zd. 2 Konstytucji RP. Oznacza to, że tryb potwierdzania skierowania na leczenie uzdrowiskowe (rehabilitację) może obejmować wskazanie przez oddział wojewódzki NFZ rodzaju leczenia uzdrowiskowego, daty jego rozpoczęcia czy właściwego zakładu lecznictwa uzdrowiskowego. Sposób postępowania dotyczący potwierdzenia skierowania na leczenie uzdrowiskowe może i powinien prowadzić do pełnej konkretyzacji warunków, na jakich świadczeniobiorca skorzysta z tego typu świadczeń opieki zdrowotnej.

W przypadku skierowania na leczenie uzdrowiskowe w warunkach ambulatoryjnych, potwierdzonego przez właściwy oddział wojewódzki NFZ, świadczeniobiorca uzgadnia termin rozpoczęcia leczenia uzdrowiskowego z zakładem lecznictwa uzdrowiskowego, do którego otrzymał skierowanie, nie później niż 14 dni przed dniem rozpoczęcia leczenia. Zakład lecznictwa uzdrowiskowego potwierdza świadczeniobiorcy uzgodniony termin rozpoczęcia leczenia uzdrowiskowego w warunkach ambulatoryjnych $\mathrm{w}$ formie pisemnej lub elektronicznej. Oddział wojewódzki NFZ doręcza wówczas świadczeniobiorcy potwierdzone skierowanie nie później niż 14 dni przed dniem rozpoczęcia leczenia. Doręczając skierowanie na leczenie w sanatorium uzdrowiskowym, oddział wojewódzki NFZ informuje o zasadach odpłatności za pobyt w sanatorium, w tym, jeżeli dotyczy, o całkowitych kosztach za pobyt opiekuna. W przypadkach szczególnie uzasadnionych, po uzgodnieniu ze świadczeniobiorca, może mu zostać doręczone potwierdzone skierowanie, za zgodą świadczeniodawcy wyrażoną $w$ formie pisemnej lub elektronicznej, w terminie innym niż 14 dni, jednak nie krótszym niż 3 dni przed dniem rozpoczęcia leczenia. Uzgodnienie ze świadczeniobiorca polega na uzyskaniu jego zgody w rozmowie telefonicznej, $\mathrm{w}$ formie pisemnej lub elektronicznej.

Rozporządzenie w $\S 5$ ust. 1-3 reguluje natomiast procedurę niepotwierdzenia skierowania. Następuje to w sytuacji, gdy oddział wojewódzki NFZ nie potwierdził, w przypadku gdy lekarz specjalista nie zaaprobował celowości skierowania. Wówczas jest ono zwracane lekarzowi, który je wystawil, wraz z podaniem przyczyny odmowy potwierdzenia skierowania. Oddział wojewódzki NFZ zawiadamia świadczeniobiorcę o niepotwierdzeniu skierowania wraz z podaniem przyczyny odmowy potwierdzenia skierowania, nie później niż 30 dni od dnia otrzymania skierowania. Jak słusznie zauważa D. Karkowska, „[s]amo zagadnienie ograniczania prawa pacjenta do świadczenia uzdrowiskowego na 
podstawie jednostronnego działania funduszu budzi spore watpliwo-

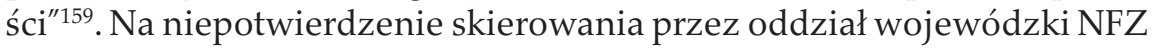
nie przysługuje odwołanie. Jak podnoszą J. Nowak-Kubiak i B. Łukasik, „przepis dotyczący braku prawa do odwołania od odmowy potwierdzenia nie przesądza jednak o braku prawa do kontroli takiej odmowy"160.

Skierowanie, którego oddział wojewódzki NFZ nie potwierdził z powodu braku miejsc w odpowiednich zakładach lecznictwa uzdrowiskowego, jest składane do dokumentacji prowadzonej przez ten oddział, który to zawiadamia świadczeniobiorcę o przyczynie niepotwierdzenia, nie później niż 30 dni od otrzymania skierowania ( $\$ 6$ ust. 1-3 rozporządzenia). Skierowanie powinno być rozpatrzone przez oddział wojewódzki NFZ w terminie 30 dni od dnia jego wpływu do tego oddziału. Termin ten może być przedłużony, nie więcej jednak niż o 14 dni ( $\$ 7$ rozporządzenia). Obecnie uchylono procedurę weryfikacji skierowania co 18 miesięcy ${ }^{161}$.

Oddział wojewódzki NFZ prowadzi listę świadczeniobiorców, którzy nie uzyskali potwierdzenia skierowania ${ }^{162}$. Świadczeniobiorca powinien być poinformowany pisemnie o swojej kolejności na liście świadczeniobiorców. Oddział potwierdza skierowanie wystawione świadczeniobiorcy, który znajduje się na liście, w pierwszej kolejności, jeżeli są miejsca w odpowiednich zakładach lecznictwa uzdrowiskowego, przewidziane w umowach z tymi zakładami ( 88 rozporządzenia). Zdaniem K. Celińskiej-Grzegorczyk ${ }^{163}$, choć lista oczekujących na leczenie uzdrowiskowe nie mieści się w dyspozycji art. 20 u.ś.o.z. - regulującego ogólne kwestie tzw. kolejki w dostępie do świadczen ${ }^{164}$ - w szczególności zaś jest prowadzona przez oddział NFZ, a nie przez świadczeniodawcę, to wpis na nią ma charakter czynności faktycznej.

Biorąc pod uwagę problem kolejności w dostępie do świadczeń zdrowotnych z zakresu lecznictwa uzdrowiskowego, ", $[\mathrm{k}]$ onieczne jest wdrożenie systemu umożliwiającego oczekiwanie (wg PESEL) na realizację

\footnotetext{
${ }^{159}$ D. Karkowska, Prawa pacjenta, s. 293.

${ }^{160} \mathrm{~J}$. Nowak-Kubiak, B. Łukasik, Ustawa o świadczeniach opieki zdrowotnej finansowanych ze środków publicznych. Komentarz, Warszawa 2010, s. 109.

${ }^{161}$ Zob. § 1 pkt 2 rozporządzenia zmieniającego Ministra Zdrowia z dnia 4 VI 2019 r.

162 Pomocnym narzędziem w celu ułatwienia dostępu do informacji o procesie potwierdzenia skierowania na leczenie uzdrowiskowe jest przeglądarka skierowań. Zob. https://skierowania.nfz.gov.pl (dostęp: 10 III 2020).

${ }^{163}$ K. Celińska-Grzegorczyk, Glosa do uchwały z dnia 16 grudnia 2013 r., II GPS/13, „Zeszyty Naukowe Sądownictwa Administracyjnego" 2014, nr 5, s. 176-182.

${ }^{164}$ J. Nowak-Kubiak, B. Lukasik, op. cit., s. 57.
} 
świadczenia wyłącznie jednego rodzaju (rehabilitacja lecznicza lub lecznictwo uzdrowiskowe) oraz wyłącznie u jednego świadczeniodawcy, a zatem likwidację «sztucznych» kolejek w rehabilitacji przewlekłej. Wskazane jest utworzenie elektronicznej «bazy» pacjentów poddawanych różnym formom rehabilitacji, $w$ celu monitorowania i koordynowania przebiegu rehabilitacji pacjenta w ramach całego systemu opieki rehabilitacyjnej"165.

\subsection{Charakter prawny skierowania na leczenie uzdrowiskowe}

Z przeprowadzonych badań wynika, że o ile zasadniczo największy zasięg władztwa zakładowego jest $\mathrm{w}$ jednym $\mathrm{z}$ rodzajów zakładów lecznictwa uzdrowiskowego - w szpitalu uzdrowiskowym, o tyle w aktualnym stanie prawnym nie należy wiązać instytucji skierowania wyłącznie ze stosunkiem zakładowym. Przedmiotem skierowania jest stan pacjenta, który kwalifikuje go, zdaniem osoby uprawnionej (lekarza), do orzekania o przyjęciu i pobycie w zakładzie lecznictwa uzdrowiskowego. W orzecznictwie przyjęto, że skierowanie lub odmowa skierowania jest aktem wiedzy osoby wydającej takie skierowanie ${ }^{166}$, a jednocześnie uznano, że skierowanie jest aktem kończącym określoną procedurę medyczna, który tym samym umożliwia rozpoczęcie kolejnego etapu postępowania. Wydanie każdego skierowania wymaga od podmiotu uprawnionego zachowania należytej staranności, kierowania się odpowiednimi wymaganiami aktualnej wiedzy medycznej i zasadami etyki zawodowej. Wola pacjenta wyrażana jest poprzez osobiste złożenie oświadczenia pacjenta, jego przedstawiciela ustawowego bądź opiekuna faktycznego $\mathrm{w}$ formie wymaganej przez odrębne przepisy. Charakter prawny oświadczenia nie powinien budzić wątpliwości. Zgodnie z art. 60 k.c. wola osoby dokonującej czynności prawnej może być wyrażona przez każde zachowanie się tej osoby, które ujawnia wolę w sposób dostateczny. Złożenie oświadczenia o wyrażeniu zgody na przyjęcie do przedmiotowego zakładu zawiera w sobie w sposób dostateczny uzewnętrznienie zamiarów tej osoby, w konsekwencji przyszłego użytkownika.

Skierowanie jest zaświadczeniem lekarskim, o którym mówi KEL ${ }^{167}$. Wydawanie zaświadczeń lekarskich jest dozwolone jedynie na podstawie aktualnego badania lub odpowiedniej dokumentacji. Bez zgody osoby

\footnotetext{
${ }^{165}$ Raport, s. 137.

${ }^{166}$ Wyrok WSA w Warszawie z 27 IX 2005 r., sygn. VI SA/Wa 828/05, LEX nr 195027.

167 Por. np. M. Nesterowicz, Prawo medyczne, Toruń 2000, s. 40.
} 
skierowanej nie jest możliwe przyjęcie do zakładu lecznictwa uzdrowiskowego. Niektóre zaświadczenia lekarskie są klasycznymi dokumentami potwierdzającymi, zawierającymi element oceny, wystawianymi przez niektóre podmioty zaliczone do organów administracji w szerokim znaczeniu (organy administrujące, organy administracji w znaczeniu funkcjonalnym $)^{168}$. Zaświadczenia lekarskie nie są zaświadczeniami w rozumieniu Kodeksu postępowania administracyjnego ${ }^{169}$, mają bowiem niejednolity charakter prawny. Mogą to być orzeczenia lekarskie oraz tzw. stwierdzenia lekarskie. Jak się przyjmuje ${ }^{170}$, orzeczenia lekarskie obejmują nie tylko stwierdzenia, ale i oceny, do jakich upoważnia aktualna wiedza medyczna, przeprowadzane pod kątem potrzeb wynikających z celu wydania danego orzeczenia, czynności o charakterze stwierdzenia mogą zaś dotyczyć wszystkich okoliczności, które dadzą się ustalić w sposób niebudzący wątpliwości w świetle nauk medycznych.

W doktrynie i w orzecznictwie sądów administracyjnych nie budzi wątpliwości charakter tego środka: skierowanie nie jest aktem administracyjnym ${ }^{171}$, ponieważ nie jest skierowane na wywołanie konkretnych, indywidualnie oznaczonych skutków prawnych. Skierowanie nie jest decyzją administracyjna, gdyż nie stwierdza o nabyciu przez użytkownika prawa podmiotowego, lecz powoduje tylko udzielanie świadczeń przez właściwą jednostkę organizacyjną. Skierowanie jest zatem czynnością materialno-techniczną, sporządzoną w postaci dokumentu urzędowego - potwierdzającego określone fakty lub stan prawny ${ }^{172}$ - przez uprawniony podmiot $\mathrm{w}$ zakresie spraw poruczonych $\mathrm{z}$ mocy prawa. Wydaje się, że "przyjęcie" i "wypisanie" "do" i "z" zakładu lecznictwa uzdrowiskowego nie dotyczy sfery zewnętrznej administracji, ale raczej sfery wewnętrznej, wobec czego nie istnieje prawna możliwość wydania decyzji administracyjnej w tym zakresie. Decyzja według SN jest

${ }^{168}$ K. Chorąży, Z. Kmiecik, Zaświadczenia według kodeksu postępowania administracyjnego a inne akty potwierdzajace, w: Administracja publiczna u progu XXI wieku. Prace dedykowane prof. zw. dr. hab. Janowi Szreniawskiemu z okazji Jubileuszu 45-lecia pracy naukowej, Przemyśl 2000, s. 143.

169 Ustawa z dnia 14 VI 1960 r. Kodeks postępowania administracyjnego (tekst jedn. Dz.U. 2020, poz. 256), dalej „k.p.a.”.

${ }^{170}$ K. Chorąży, Z. Kmiecik, Zaświadczenia..., s. 144.

${ }^{171}$ R. Kędziora, Ogólne postępowanie administracyjne, Warszawa 2008, s. 402; K. Chorąży, Z. Kmiecik, Wydawanie zaświadczeń - kwestie nie rozstrzygnięte w literaturze, "Samorząd Terytorialny" 2000, nr 6, s. 71.

${ }^{172}$ J. Bukowska, Prawne formy działania administracji, w: Nauka administracji, pod red. Z. Cieślaka, Warszawa 2017, s. 114-116. 
kwalifikowanym przejawem woli organu, wydawanym na podstawie powszechnie obowiązujących przepisów prawa, władczym, zewnętrznym, rozstrzygającym konkretną sprawę co do konkretnej osoby, wydanym $\mathrm{w}$ postępowaniu o prawnie unormowanej procedurze ${ }^{173}$, natomiast "[s]twierdzenie zawarte w art. $104 \S 1$ k.p.a., że załatwienie sprawy następuje przez wydanie decyzji, odnosi się tylko do sytuacji, gdy z mocy przepisów prawa materialnego lub innych załatwienie sprawy powinno nastąpić w tej formie prawnej"174.

Wobec zarysowania się w ocenie sądów administracyjnych dwóch przeciwstawnych stanowisk odnośnie do przyjmowanego kierunku interpretacji - kwestia sporna dotyczy tego, czy przedmiotowe skierowanie jest to czynność z zakresu administracji publicznej dotycząca uprawnień lub obowiązków wynikających z przepisów prawa. Naczelny Sąd Administracyjny w składzie 7 sędziów w uchwale z 16 grudnia 2013 r. ${ }^{175}$ zważył, że potwierdzenie skierowania na leczenie uzdrowiskowe wydane na podstawie art. 33 ust. 2 u.ś.o.z. jest czynnością, o której mowa w art. $3 \S 2$ pkt 4 p.p.s.a., czyli czynnością z zakresu administracji publicznej dotyczącą uprawnień lub obowiązków wynikających z przepisów prawa, natomiast odmowa potwierdzenia skierowania taką czynnością nie jest. Obecnie zgodnie z art. 33 ust. 2 zd. 2 u.ś.o.z. do potwierdzenia oraz odmowy potwierdzenia skierowania nie stosuje się przepisów k.p.a. Zmiana ta ${ }^{176}$ pozwala stwierdzić, że właśnie przywołana uchwała NSA determinowała ingerencję ustawodawcy w dotychczasowe brzmienie art. 33 ust. 2 u.ś.o.z. - „[o]znacza to, że organ rozpatrując wniosek o potwierdzenie skierowania na leczenie uzdrowiskowe nie jest również związany zasadami ogólnymi postępowania administracyjnego, które m.in. nakładają na niego obowiązek załatwienia sprawy z uwzględnieniem słusznego interesu strony (art. 7 k.p.a.), a także do prowadzenia postępowania w sposób budzący zaufanie jego uczestników do władzy publicznej (art. 8 k.p.a.)" 177.

\footnotetext{
${ }^{173}$ Uchwała ICiA SN z 5 II 1988 r., sygn. III AZP 1/88, OSPiKA 1989, nr 5, poz. 59.

${ }^{174}$ Wyrok NSA z 17 XII 1985 r., sygn. III SA 988/85, OSPiKA 1987, nr 5-6, poz. 116, z glosą J. Borkowskiego, ONSA 1985, z. 2, poz. 38.

${ }^{175}$ Uchwała 7 sędziów NSA z 16 XII 2013 r., sygn. II GSP 2/13, http://orzeczenia.nsa. gov.pl/doc/A315C34C26 (dostęp: 10 III 2020), i zawarty tam szeroki wybór orzecznictwa.

${ }_{176}$ Zob. art. 1 pkt 26 Ustawy z dnia 22 VII 2014 r. o zmianie ustawy o świadczeniach opieki zdrowotnej finansowanych ze środków publicznych oraz niektórych innych ustaw (Dz.U. poz. 1138), której przepisy weszły w życie z dniem 1 I 2015 r. Zob. także K. Celińska-Grzegorczyk, op. cit., s. 176-182.

177 Zob. przywoływany już wyrok NSA z 23 I 2018 r., sygn. II GSK 4944/16.
} 


\subsection{Zasady kierowania i kwalifikowania pacjentów do zakładów lecznictwa uzdrowiskowego}

Zgodnie z art. 19 ust. 13 ustawy uzdrowiskowej Minister Zdrowia określił, w drodze rozporządzenia, zasady kierowania i kwalifikowania pacjentów do zakładów lecznictwa uzdrowiskowego, kierując się bezpieczeństwem pacjenta, a także wskazaniami nauki i praktyki. W tym zakresie obowiązuje Rozporządzenie Ministra Zdrowia z dnia 5 stycznia 2012 r. w sprawie zasad kierowania i kwalifikowania pacjentów do zakładów lecznictwa uzdrowiskowego ${ }^{178}$. Określa ono wskazania i przeciwwskazania do leczenia uzdrowiskowego (rehabilitacji) stanowiące podstawę kwalifikowania pacjenta ( $§ 1$ ). Według $\S 4$ tego aktu przy kwalifikowaniu pacjenta do zakładu lecznictwa uzdrowiskowego lekarz ocenia: (1) stan zdrowia pacjenta; (2) możliwość leczenia uzdrowiskowego przy wykorzystaniu właściwości naturalnych surowców leczniczych; (3) przebieg choroby będącej wskazaniem do leczenia uzdrowiskowego lub rehabilitacji uzdrowiskowej, w ramach kierunków leczniczych uzdrowisk; (4) efekty przebytego w przeszłości leczenia uzdrowiskowego lub rehabilitacji uzdrowiskowej, jeżeli pacjent korzystał z tej formy leczenia lub rehabilitacji; (5) zdolność pacjenta do samoobsługi i samodzielnego poruszania się lub zdolność pacjenta do samoobsługi i samodzielnego przemieszczania się na wózku inwalidzkim. Zwłaszcza ta ostatnia przesłanka według Rzecznika Praw Obywatelskich (RPO) stanowi problem związany z dostępnością świadczeń z zakresu leczenia uzdrowiskowego dla pacjentów z niepełnosprawnościami i seniorów wymagających $w$ codziennym funkcjonowaniu wsparcia osoby bliskiej. Jak wynika z oświadczenia, „RPO zgadza się, że pacjent może być w takim stanie, że nie powinno się go kierować do sanatorium. Jednak niepełnosprawność nie może być jedynym czynnikiem decydującym o niemożności skorzystania z uzdrowiska"179. Rozwiązaniem problemu mogłoby być powiązanie leczenia uzdrowiskowego z wprowadzeniem usług asystenckich dla tego typu pacjentów, tak by nie byli oni wykluczeni z możliwości korzystania $z$ tej formy leczenia ze względu np. na niepełnosprawność czy zaawansowany wiek.

178 Tekst jedn. Dz.U. poz. 14.

${ }^{179}$ Zob. https:/www.politykazdrowotna.com/45818,osoby-niesamodzielne-dyskryminowane-przy-leczeniu-uzdrowiskowym, 10 VI 2019 r. (dostęp: 10 III 2020). 
Przeciwwskazania określono dla wszystkich rodzajów leczenia uzdrowiskowego i rehabilitacji ${ }^{180}$. Z grupy ogólnych przeciwwskazań do leczenia uzdrowiskowego usunięto m.in. upośledzenie umysłowe i choroby psychiczne. Przeciwwskazania dotyczą pacjentów, u których leczenie finansowane jest ze środków publicznych i tych korzystających z niego odpłatnie. Na mocy $\S 6$ ust. 4-6 rozporządzenia wprowadzono dodatkowy warunek kwalifikowania do zakładu - konieczność przedstawienia opinii lekarza specjalisty - dotyczący pacjentów po przeszczepie: (1) narządu (biorców narządu); (2) szpiku kostnego; (3) poddawanych dializoterapii. Jednoznaczna ocena wymogu przedstawienia takiej opinii nie jest prosta. $Z$ jednej strony może się wydawać, że rodzi ona powód do ograniczenia możliwości korzystania przez pacjenta z leczenia uzdrowiskowego w ramach NFZ. Z drugiej jednak strony przepis ten może mieć na celu uchronienie pacjenta o obniżonej odporności na zachorowanie, trudno więc byłoby w tym miejscu zarzucać ryzyko arbitralnej limitacji.

\section{Leczenie uzdrowiskowe jako gwarantowane świadczenie opieki zdrowotnej}

\subsection{Model ubezpieczenia zdrowotnego}

Zgodnie z art. 16 ust. 1-3 ustawy uzdrowiskowej świadczeniobiorcy w rozumieniu przepisów u.ś.o.z. korzystają z lecznictwa uzdrowiskowego na zasadach określonych w przepisach o świadczeniach opieki zdrowotnej finansowanych ze środków publicznych (ust. 1). Osoby inne niż świadczeniobiorcy oraz świadczeniobiorcy, którzy nie uzyskali skierowania na leczenie uzdrowiskowe albo rehabilitację uzdrowiskową na zasadach określonych w przepisach ustawy, mogą korzystać z lecznictwa uzdrowiskowego za odpłatnością w wysokości ustalonej przez zakład lecznictwa uzdrowiskowego, po przedstawieniu zaświadczenia o braku przeciwwskazań do korzystania z danego rodzaju świadczeń

${ }^{180}$ Do przeciwwskazań obecnie należą ( $(5)$ : stan chorobowy, w którym leczenie uzdrowiskowe albo rehabilitacja uzdrowiskowa przy wykorzystaniu właściwości naturalnych surowców leczniczych mogłyby spowodować pogorszenie stanu zdrowia pacjenta; choroba zakaźna w fazie ostrej; ciąża i połóg; czynna choroba nowotworowa oraz okres przed upływem: 5 lat w przypadku: czerniaka złośliwego, białaczki, ziarnicy złośliwej, chłoniaków złośliwych, nowotworów nerki, 12 miesięcy w przypadku innych nowotworów złośliwych - od zakończenia leczenia operacyjnego, chemioterapii lub radioterapii, z wyłączeniem leczenia hormonalnego. 
zdrowotnych w danym uzdrowisku (ust. 2). Osoby te mogą korzystać z lecznictwa uzdrowiskowego, jeżeli zapewniono korzystanie $\mathrm{z}$ tego lecznictwa świadczeniobiorcom korzystającym z lecznictwa uzdrowiskowego na zasadach określonych w u.ś.o.z. (ust. 3).

Obecny model opieki zdrowotnej doktryna prawa zalicza do prawa zabezpieczenia społecznego - jako ubezpieczeniowej części ${ }^{181}$, natomiast "[z]abezpieczenie społeczne to całokształt środków i działań (instytucji) publicznych, przy których pomocy społeczeństwo stara się zabezpieczyć swych obywateli przed groźbą niezaspokojenia podstawowych potrzeb, społecznie uznanych za ważne"182. W Polsce zakres ryzyka ubezpieczeniowego określa art. 15 u.ś.o.z., obejmując także prewencję. Ustawodawca opowiedział się za ubezpieczeniową formą zabezpieczenia przed ryzykiem "braku zdrowia” lub „niezdrowia”183. Jak już wiadomo, głównym źródłem finansowania systemu ochrony zdrowia $^{184}$ jest obowiązkowa składka na ubezpieczenie zdrowotne, odprowadzana do NFZ. Uczestnikami systemu są: świadczeniobiorcy (pacjenci), płatnik (NFZ) i świadczeniodawcy (podmioty lecznicze).

Podstawową formą ochrony zdrowia w Polsce jest powszechne ubezpieczenie zdrowotne. Zdaniem D. Karkowskiej ustawodawca dopuszcza funkcjonowanie modelu ubezpieczeniowo-zaopatrzeniowego ${ }^{185}$. Metoda ubezpieczeniowa jest zasadnicza, ale nie jedyną forma, co wynika już z samego tytułu u.ś.o.z. Ustawodawca, w porównaniu z wcześniejszymi uregulowaniami, odstąpił od pojęcia "ubezpieczenie" i przyjętych rozwiązań organizacyjno-finansowych na rzecz zbiorczego terminu „Świadczeniobiorcy", które oznacza podmiot uprawniony do świadczeń opieki zdrowotnej finansowanych ze środków publicznych i nie jest jednoznaczne $\mathrm{z}$ „osobą ubezpieczoną" (art. 2 u.ś.o.z.) ${ }^{186}$. Rozróżnienie świadczeniobiorców na osoby ubezpieczone i nieubezpieczone jest istotne ze względu na podmiot finansujący leczenie. W przypadku osób ubezpieczonych ich leczenie jest finansowane ze środków pochodzących ze składek na ubezpieczenie zdrowotne z dyspozycji NFZ. Leczenie

${ }^{181}$ J. Jończyk, Prawo zabezpieczenia społecznego, Kraków 2006, s. 250 i n.

182 J. Piotrowski, Zabezpieczenie społeczne, Warszawa 1966, s. 28.

183 J. Jończyk, Prawo zabezpieczenia..., s. 250 i n.

${ }^{184}$ P. Lenio, Publicznoprawne źródła finansowania ochrony zdrowia, Warszawa 2018, s. $141-157,211$ i n.

185 D. Karkowska, Prawa Pacjenta, s. 226.

${ }^{186} \mathrm{~K}$. Orzechowski, Uwagi w sprawie ubezpieczeniowego charakteru ubezpieczenia zdrowotnego, w: Finansowanie ochrony zdrowia po reformie - ujęcie regionalne, pod red. M. Węgrzyn, Wrocław 2003, s. 137 n. 
pozostałych świadczeniobiorców uprawnionych do bezpłatnych świadczeń zdrowotnych niebędących osobami ubezpieczonymi odbywa się na koszt budżetu państwa poprzez przyznanie na ten cel dotacji z budżetu państwa dla NFZ (art. 97 u.ś.o.z.).

Orzecznictwo SN utrwala pogląd, że regulacja prawa ubezpieczenia zdrowotnego w Polsce ma charakter mieszany, czyli publiczno-prywatny ${ }^{187}$. Ubezpieczenia zdrowotne obejmują trzy typy stosunków prawnych jako współzależne i niezbędne do realizacji prawa do świadczeń $z$ ubezpieczenia zdrowotnego ${ }^{188}$. Podstawowym stosunkiem jest stosunek ubezpieczenia łączący ubezpieczonego z NFZ, choć jego charakter nie jest jednolity ${ }^{189}$. Przyjęto, że to stosunek o charakterze zobowiązaniowym, mający swoje źródło w ustawie ${ }^{190}$. Przy czym wiele elementów tego stosunku ma charakter publicznoprawny ze względu na obowiązek podlegania ubezpieczeniu, sposób ustalania i pobierania składek oraz pozycję ustrojową NFZ, co wskazuje, że jest to stosunek o charakterze administracyjnoprawnym ${ }^{191}$.

Według art. 15 u.ś.o.z. świadczeniobiorcy maja, na zasadach określonych w ustawie, prawo do świadczeń opieki zdrowotnej, których celem jest zachowanie zdrowia, zapobieganie chorobom i urazom, wczesne wykrywanie chorób, leczenie, pielęgnacja oraz zapobieganie niepełnosprawności i jej ograniczanie. Oznacza to, że na tej podstawie przysługują im świadczenia gwarantowane z zakresu lecznictwa uzdrowiskowego (ust. 2 pkt 8 u.ś.o.z.).

\subsection{Umowa pomiędzy świadczeniodawcą a NFZ}

Przepisy art. 15 u.ś.o.z. gruntownie znowelizowano, wprowadzając fundamentalne zmiany w systemie finansowania świadczeń ze środków publicznych dotyczące tzw. koszyka świadczeń, zmieniając tzw. koszyk negatywny w koszyk pozytywny ${ }^{192}$. Tym samym obecne brzmienie art. 15

${ }^{187}$ Por. uchwała SN z 24 I 2007 r., sygn. III UZP 4/06, OSNP 2007/15-16, poz. 226.

188 Por. J. Jończyk, Strony i stosunki..., s. 22 i n.

${ }_{189}$ Zob. W. Sanetra, Stosunki z zakresu ubezpieczenia zdrowotnego - jedność w różnorodności, „Przegląd Ubezpieczeń Społecznych i Gospodarczych” 2001, nr 3.

${ }^{190}$ T. Zimna, Zawieranie umów o udzielanie świadczeń opieki zdrowotnej, Warszawa 2007, s. 22.

${ }^{191}$ Por. wyrok SN z 7 VIII 2003 r., sygn. IV CKN 393/01, LEX nr 279804.

192 Zob. Ustawa z dnia 25 VI 2009 r. o zmianie ustawy o świadczeniach opieki zdrowotnej finansowanych ze środków publicznych oraz ustawy o cenach (Dz.U. Nr 118, 
ust. 2 u.ś.o.z. współgra z przedmiotami umów o udzielanie świadczeń opieki zdrowotnej określonymi aktualnie w Rozporządzeniu Ministra Zdrowia z dnia 8 września 2015 r. w sprawie ogólnych warunków umów o udzielanie świadczeń opieki zdrowotnej ${ }^{193}$ i wyraźnie wskazuje, że świadczeniobiorcom przysługują tylko świadczenia gwarantowane, których wykaz określono w rozporządzeniach Ministra Zdrowia wydanych na podstawie art. $31 \mathrm{~d}$ u.ś.o.z., a zatem m.in. z zakresu lecznictwa uzdrowiskowego ${ }^{194}$. Świadczeniodawca udziela świadczeń przez cały okres obowiązywania umowy zawartej z NFZ - na podstawie umowy zawartej w specjalnym ustawowym trybie ${ }^{195}$ (art. 132-161b u.ś.o.z.) - zgodnie $\mathrm{z}$ określonym $\mathrm{w}$ umowie harmonogramem pracy i planem rzeczowo-finansowym. Oznacza to, że świadczeniobiorca ma prawo do ciągłości udzielania tych świadczeń, co wiąże się z obowiązkiem świadczeniodawcy do ich udzielania przez cały okres obowiązywania umowy. Zapewniając pacjentowi (świadczeniobiorcy) ciągłość świadczeń opieki zdrowotnej, Prezes NFZ w drodze zarządzenia ${ }^{196}$ określił obowiązki poszczególnych świadczeniodawców. Ze względu na ograniczone ramy opracowania nie można poddać szczegółowej analizie zawierania umów w rodzaju lecznictwo uzdrowiskowe. Niemniej na podstawie tych przepisów można stwierdzić, że podstawowe źródło finansowania z tytułu prowadzonej działalności leczniczej dla zdecydowanej większości uzdrowisk i poszczególnych zakładów lecznictwa uzdrowiskowego stanowią środki publiczne otrzymywane od NFZ ${ }^{197}$. Zgodnie z art. 132 ust. 1-2 u.ś.o.z. zasadniczo podstawą udzielania świadczeń

poz. 989); A. Pietraszewska-Macheta, Komentarz do art. 15, w: Ustawa o świadczeniach opieki zdrowotnej finansowanych ze środków publicznych. Komentarz, pod red. A. Pietraszewskiej-Machety, Warszawa 2016, LEX/el. Odnośnie do braku precyzyjności poszczególnych procedur medycznych w kontekście art. 15 u.ś.o.z. wypowiedział się NSA w wyroku z 21 I 2015 r., sygn. II GSK 2054/13, http://orzeczenia.nsa.gov.pl/doc/D2D76EC0C4 (dostęp: 10 III 2020).

${ }_{193}$ Tekst jedn. Dz.U. 2016, poz. 1146, dalej „r.o.w.u.”. Por. art. 137 ust. 2 u.ś.o.z.

${ }^{194}$ Zgodnie z art. 31a ust. 1 u.ś.o.z. podstawą zakwalifikowania świadczenia opieki zdrowotnej jako świadczenia gwarantowanego jest jego ocena. Organem uprawnionym do wprowadzania świadczeń do wykazu świadczeń gwarantowanych jest Minister Zdrowia. Wykaz danego świadczenia określa poziom i sposób ich finansowania (w sposób kwotowy lub procentowy), w tym limity cen oraz warunki jego realizacji.

${ }^{195}$ M. Paszkowska, op. cit., s. 259 i n.

196 Zarządzenie nr 63/2016/DSM Prezesa NFZ z dnia 29 VI 2016 r. w sprawie określenia warunków zawierania i realizacji umów w rodzaju lecznictwo uzdrowiskowe (tekst jedn. Biul. Inf. NFZ 2018, poz. 13).

${ }^{197}$ M. Paszkowska, op. cit., s. 259. 
opieki zdrowotnej finansowanych ze środków publicznych przez NFZ jest umowa o udzielanie świadczeń opieki zdrowotnej zawarta pomiędzy świadczeniodawcą a NFZ. Umowa o udzielanie świadczeń opieki zdrowotnej może być zawarta wyłącznie ze świadczeniodawca, który został wybrany do udzielania świadczeń opieki zdrowotnej na zasadach określonych w VI dziale zatytułowanym „Postępowanie w sprawie zawarcia umów ze świadczeniodawcami". Ta regulacja daje podstawy do stwierdzenia, że umowy z zakresu lecznictwa uzdrowiskowego są w dużym stopniu podporządkowane NFZ. Umowa o udzielenie świadczeń opieki zdrowotnej ma charakter umowy wzajemnej, odpłatnej, dwustronnie obowiązującej, w której każda ze stron jest jednocześnie wierzycielem i płatnikiem. Pomiędzy NFZ a świadczeniodawcą istnieje więź prawna o charakterze cywilnoprawnym, znajdująca swoje źródło $\mathrm{w}$ umowie o udzielenie świadczeń zdrowotnych ${ }^{198}$. Stosownie do art. 155 u.ś.o.z. do umów o udzielanie świadczeń opieki zdrowotnej stosuje się przepisy k.c., jeżeli przepisy ustawy nie stanowią inaczej. Warto tu ponadto zaznaczyć, że według art. 139 u.ś.o.z. zawieranie przez Fundusz umów o udzielanie świadczeń opieki zdrowotnej odbywa się po przeprowadzeniu postępowania w trybie konkursu ofert albo rokowań. Natomiast w świetle art. 146 u.ś.o.z. Prezes NFZ określa: (1) przedmiot postępowania w sprawie zawarcia umowy o udzielanie świadczeń opieki zdrowotnej; (2) szczegółowe warunki umów o udzielanie świadczeń opieki zdrowotnej, obejmujące w szczególności obszar terytorialny, dla którego jest przeprowadzane postępowanie w sprawie zawarcia umów ze świadczeniodawcami, z uwzględnieniem taryfy świadczeń w przypadku jej ustalenia w danym zakresie oraz biorąc pod uwagę konieczność stosowania ułatwień w obiegu dokumentacji, w tym ich elektronizacji.

\section{3. Świadczenia gwarantowane z zakresu lecznictwa uzdrowiskowego}

Istotne regulacje dla pacjentów zawiera Rozporządzenie Ministra Zdrowia z dnia 23 lipca 2013 r. w sprawie świadczeń gwarantowanych z zakresu lecznictwa uzdrowiskowego ${ }^{199}$, określające: wykaz oraz warunki

198 T. Zimna, op. cit., s. 27.

199 Tekst jedn. Dz.U. 2019, poz. 168. Na potrzeby rozporządzenia w słowniczku wyjaśniono także następujące określenia: lekarz specjalista ( $\$ 2$ pkt 1 ), dzień ( $\$ 2$ pkt 2), kierunek leczniczy (§ 2 pkt 3). 
realizacji świadczeń gwarantowanych z zakresu lecznictwa uzdrowiskowego oraz poziom i sposób finansowania świadczeń gwarantowanych. Zgodnie z \& 3 ust. 2-5 tego aktu świadczenia gwarantowane są realizowane w warunkach ambulatoryjnych i stacjonarnych. Zróżnicowany jest czas trwania tego świadczenia, który w zależności od rodzaju zakładu lecznictwa uzdrowiskowego i wieku pacjenta wynosi: (1) 27 dni - dla uzdrowiskowego leczenia szpitalnego dzieci w wieku od 3 do 18 lat; (2) 21 dni - dla uzdrowiskowego leczenia sanatoryjnego dzieci: w wieku od 7 do 18 lat; w wieku od 3 do 6 lat pod opieką dorosłych; uzdrowiskowego leczenia szpitalnego dorosłych; uzdrowiskowego leczenia sanatoryjnego dorosłych; (3) 28 dni - dla uzdrowiskowej rehabilitacji dla dorosłych: w szpitalu uzdrowiskowym; w sanatorium uzdrowiskowym; (4) od 6 do 18 dni - dla uzdrowiskowego leczenia ambulatoryjnego dorosłych i dzieci. Czas leczenia może być przedłużony jednokrotnie na okres nieprzekraczający określonego czasu za zgodą oddziału wojewódzkiego NFZ, który potwierdził skierowanie na leczenie uzdrowiskowe. W zakresie koniecznym do wykonania świadczeń gwarantowanych świadczeniodawca zapewnia świadczeniobiorcy nieodpłatnie: badania diagnostyczne; leki i wyroby medyczne (§ 5). Rozporządzenie w $\S 6-7$ szczegółowo ustala poziomy warunków zakwaterowania w sanatorium uzdrowiskowym, ze względu na standard pokoju ${ }^{200}$. Świadczeniobiorca dokonuje jego wyboru, biorąc pod uwagę możliwości świadczeniodawcy. W jednej z tez przytaczanego wcześniej wyroku podniesiono: „[b]rak możliwości zakwaterowania podczas leczenia uzdrowiskowego w pokoju jednoosobowym, jeśli taka konieczność nie wynika z udokumentowanych wskazań medycznych, nie może być uznana za okoliczność uzasadniającą zwrot potwierdzonego skierowania przez świadczeniobiorcę"201. Rozporządzenie określa także poziom finansowania przez świadczeniobiorcę kosztów wyżywienia i zakwaterowania w sanatorium uzdrowiskowym za jeden dzień pobytu ${ }^{202}$.

${ }^{200}$ Gradację komfortu pokoi uwzględnia klasyfikacja od poziomu I (najwyższy) do poziomu VI (najniższy).

${ }^{201}$ Przywoływany już wyrok WSA w Warszawie z 13 II 2014 r., sygn. VI SA/Wa 2367/13.

202 Odpłatność stanowi iloczyn liczby dni pobytu i poziomu finansowania przez świadczeniobiorcę częściowych kosztów wyżywienia i zakwaterowania w sanatorium uzdrowiskowym za jeden dzień pobytu. 
Jak wynika $\mathrm{z}$ informacji NFZ ${ }^{203}$, na podstawie stanowiska Ministerstwa Zdrowia, wprowadzenie dodatkowych (wyższych) dopłat do zakwaterowania i wyżywienia dla pacjentów korzystających z leczenia uzdrowiskowego w sanatorium uzdrowiskowym w ramach potwierdzonego przez NFZ skierowania jest niezgodne z obowiązującymi przepisami.

Ustawodawca, określając zasady finansowania świadczeń gwarantowanych, realizuje zasadę terytorialnej właściwości wojewódzkiej ${ }^{204}$. Koszty leczenia uzdrowiskowego świadczeniobiorcy ponosi oddział wojewódzki NFZ właściwy ze względu na miejsce jego zamieszkania, a jeżeli nie można ustalić miejsca zamieszkania - oddział właściwy ze względu na miejsce wystawienia skierowania (art. 108 ust. 2 u.ś.o.z.). Przy czym NFZ pokrywa tylko koszty tych świadczeń, które są związane z bezpośrednią przyczyną skierowania na leczenie uzdrowiskowe. Niezależnie od objęcia powszechnym ubezpieczeniem zdrowotnym pacjent - świadczeniobiorca finansuje we własnym zakresie i ponosi koszty: przejazdu na leczenie uzdrowiskowe i powrotu z niego, częściową odpłatność za wyżywienie i zakwaterowanie w sanatorium uzdrowiskowym. Dzieci i młodzież do ukończenia lat 18, a jeżeli kształcą się dalej - do ukończenia lat 26, dzieci niepełnosprawne w znacznym stopniu - bez ograniczenia wieku, a także dzieci uprawnione do renty rodzinnej nie ponoszą odpłatności za koszty wyżywienia i zakwaterowania $\mathrm{w}$ szpitalu i sanatorium uzdrowiskowym dla dzieci (art. 33 ust. 3-4 u.ś.o.z.).

Uwagę zwraca to, że żaden przepis u.ś.o.z. nie przyznaje osobom objętym jej działaniem prawa do żądania zwrotu środków poniesionych na opiekę zdrowotną poza systemem tej ustawy. W tym zakresie nie istnieje stosunek administracyjnoprawny pomiędzy osobą domagającą się refundacji a którymkolwiek z organów wymienionych w ustawie ${ }^{205}$.

Według najnowszych danych GUS ${ }^{206}$ z 2018 r. udział cudzoziemców wśród kuracjuszy leczonych stacjonarnie wyniósł ponad 6\%. Większość $(89,7 \%)$ cudzoziemców przebywała w uzdrowiskach zlokalizowanych

${ }^{203}$ https://www.nfz.gov.pl/dla-pacjenta/leczenie-uzdrowiskowe1/ (dostęp: 10 III 2020).

${ }^{204}$ Por. J. Nowak-Kubiak, B. Łukasik, op. cit., s. 281-282.

${ }^{205}$ Zob. wyrok WSA w Warszawie z 21 V 2008 r., sygn. VII SA/Wa 2131/08, LEX nr 558759.

${ }^{206}$ GUS z 2018 r. - notka, s. 1-3. 
na terenach dwóch województw: zachodniopomorskiego i dolnośląskiego. Średni czas pobytu kuracjusza w opiece stacjonarnej wyniósł 16,4 dnia. W stosunku do $2017 \mathrm{r}$. nieznacznie zmieniła się struktura form dofinansowania pobytu kuracjuszy stacjonarnych w zakładach lecznictwa uzdrowiskowego. Ponad połowa pacjentów leczonych w opiece stacjonarnej korzystała z dofinansowania pobytu ze środków NFZ, pacjenci pełnopłatni stanowili natomiast ponad $1 / 3$ kuracjuszy.

W 2018 r. w zakładach lecznictwa uzdrowiskowego wykonano 37,1 mln różnorodnych zabiegów leczniczych (o 1,6\% więcej niż przed rokiem). Podobnie jak w roku poprzednim najczęściej udzielano zabiegów przyrodoleczniczych $(26,4 \%)$, wśród których dominowały zabiegi borowinowe $(10,7 \%)$ oraz kąpiele mineralne $(8,2 \%)$. Popularne były również zabiegi kinezyterapii (20,3\%) i elektrolecznictwo (12,9\%) oraz masaże $(10,2 \%)$.

\section{Problemy związane z dostępem do leczenia uzdrowiskowego}

Jedynie posiadanie statusu uzdrowiska pozwala na uzyskanie prawa do zawierania umów z NFZ przez zakłady lecznictwa uzdrowiskowego na świadczenie zdrowotne $\mathrm{z}$ zakresu lecznictwa uzdrowiskowego. Jak wynika $\mathrm{z}$ dostępnych informacji ${ }^{207}$, NFZ zgodnie $\mathrm{z}$ rocznym planem finansowym na 2020 r. przeznaczył na ten cel $799 \mathrm{mln}$ zł, w 2019 r. przeszło $716 \mathrm{mln}$ zł, a w 2018 r. prawie $684 \mathrm{mln}$ zł. Nakłady na leczenie uzdrowiskowe to dziś niespełna $1 \%$ ogólnych kosztów budżetu NFZ. Na efekty nie trzeba długo czekać: wydłużył się czas oczekiwania na przyjęcie do leczenia i lista oczekujących oraz walka przez zakłady o klientów komercyjnych. Sytuacja ta może doprowadzić do zachwiania relacji ceny do jakości i standardu świadczonych usług uzdrowiskowych, podczas gdy te ostatnie są czynnikiem przetargowym decydującym o uzyskaniu odpowiedniego kontraktu.

Nieco inne wyniki w zakresie dostępności do leczenia uzdrowiskowego podała jednak NIK w swojej najnowszej kontroli pt. „Realizacja zadań Narodowego Funduszu Zdrowia w 2018 roku"208, wskazując, że w procesie planowania zakupu świadczeń NFZ uwzględnił priorytety

${ }^{207} \mathrm{Z}$ badań własnych planów finansowych NFZ, http://www.nfz.gov.pl/bip/finanse-nfz/ (dostęp: 10 III 2020).

${ }^{208}$ KZD.430.006.2019 Nr ewid. 169/2019/P/19/058/KZD, s. 20. 
ogólnopolskie na rok 2018 i lata następne i odnośnie do świadczeń opieki zdrowotnej z zakresu lecznictwa uzdrowiskowego obejmowały one "sukcesywne skracanie czasu oczekiwania na potwierdzenie skierowania na leczenie uzdrowiskowe, docelowo do okresu krótszego niż 18 miesięcy od daty złożenia skierowania do oddziału wojewódzkiego NFZ (okres realizacji: lata 2018-2019). Wszystkie oddziały rozpoczęły realizację zadania i w większości przypadków sprawozdały, że liczba osób oczekujących na udzielenie świadczenia zmniejszyła się przy rosnącej liczbie zabiegów".

Niewątpliwie, lecznictwo uzdrowiskowe finansowane na odpowiednim poziomie zwiększy możliwość wykorzystania tej formy leczenia jako znakomitego elementu kompleksowej opieki i leczenia pacjenta w systemie ochrony zdrowia. Stąd rekomenduje się „sukcesywne i pilne zwiększanie w planie finansowym NFZ środków finansowych na lecznictwo uzdrowiskowe do poziomu minimum 1,4\% planowanych ogółem kosztów świadczeń opieki zdrowotnej, a przez to urealnienie stawki (ceny za tzw. osobodzień) w szpitalach i sanatoriach uzdrowiskowych oraz zwiększenie dostępności pacjentów do tej formy leczenia poprzez skrócenie kolejki na leczenie uzdrowiskowe"209.

Wady dotyczą także ścieżki kwalifikacji i potwierdzania skierowań. Wśród nich można podać następujące: (1) obciążenie płatnika kosztami prowadzenia list oczekujących, potwierdzania skierowań, rozpatrywania zwrotów czy rezygnacji; (2) duży odsetek rezygnacji i zwrotów skierowań uzależniony od ustalonego terminu i miejsca leczenia; (3) brak możliwości reagowania na późno dokonane zwroty i "niedojazdy", "pustostany" oraz niewykorzystany potencjał leczniczy w systemie opieki zdrowotnej; (4) niewykorzystany potencjał leczniczy powodujący straty dla zakładów lecznictwa uzdrowiskowego ${ }^{210}$.

Brak systemowych rozwiązań regulujących lecznictwo uzdrowiskowe dotyczy również barier prawnych odnoszących się do procedury zawierania umów pomiędzy NFZ a poszczególnymi świadczeniodawcami. Bez wątpienia, ma to wpływ na niepewną sytuację zakładów lecznictwa uzdrowiskowego w zakresie kontraktowania lecznictwa uzdrowiskowego oraz zbiurokratyzowane zasady przygotowywania ofert kontraktów dla NFZ. Trudności wiążą się też z wieloma obligatoryjnymi dla świadczeniodawców elementami samej umowy, a także z tym, że może

\footnotetext{
${ }^{209}$ Raport, s. 45.
}

${ }^{210}$ Ibidem, s. 58. 
ona zawierać zastrzeżenie o karze umownej w razie stwierdzenia niewykonania lub nienależytego wykonania umowy z przyczyn leżących po stronie świadczeniodawcy (przede wszystkim zakładu lecznictwa uzdrowiskowego).

Wśród problemów, z jakimi borykają się pacjenci, którzy chcą korzystać bądź już korzystają ze świadczeń zdrowotnych z zakresu lecznictwa uzdrowiskowego - w kontekście potwierdzenia skierowania na leczenie uzdrowiskowe - jest brak możliwości wyboru: (1) rodzaju zakładu lecznictwa uzdrowiskowego (szpital uzdrowiskowy czy sanatorium uzdrowiskowe bądź przychodnia uzdrowiskowa); (2) miejscowości uzdrowiskowej - konkretnego z nazwy uzdrowiska; (3) terminu leczenia - gdyż decyduje o tym NFZ. Inny mankament wynika z oceny celowości skierowania na leczenie uzdrowiskowe, której obecnie dokonuje lekarz specjalista balneologii i medycyny fizykalnej lub rehabilitacji medycznej zatrudniony we właściwej komórce organizacyjnej oddziału wojewódzkiego NFZ, a nie lekarz rodzinny - i ta ocena dotyczy: (1) stwierdzenia, czy ta forma leczenia jest wskazana; (2) wyboru uzdrowiska ze względu na położenie geograficzne; (3) określenia rodzaju świadczenia (uzdrowiskowe leczenie szpitalne, sanatoryjne, ambulatoryjne lub rehabilitacja uzdrowiskowa) i kierunku leczniczego uzdrowiska, do którego pacjent ma być skierowany. Minusem są także koszty związane z przyjazdem na leczenie uzdrowiskowe i z powrotem oraz możliwość pobierania przez zakład dość wysokich opłat za dodatkowe zabiegi niezwiązane bezpośrednio ze schorzeniem lub zabiegi wspólistniejące w trakcie leczenia, których nie zalecił w skierowaniu lekarz NFZ.

Problemy te potęguje powszechna praktyka wykorzystywania w leczeniu uzdrowiskowym zamienników (tj. pasta borowinowa, plastry borowinowe, żel borowinowy, płyn siarczkowy, techniczny dwutlenek węgla) zamiast naturalnych surowców leczniczych ${ }^{211}$.

Istotnym ograniczeniem dla pacjenta $\mathrm{w}$ dostępie do leczenia uzdrowiskowego jest ogłoszenie od dnia 14 marca 2020 r. do odwołania na obszarze Rzeczypospolitej Polskiej stanu zagrożenia epidemicznego w związku z zakażeniami wirusem SARS-CoV-2 ${ }^{212}$. W związku z tym we wskazanym okresie ustanawia się czasowe ograniczenie działalności

${ }^{211}$ Kontrola NIK, Wykorzystywanie naturalnych surowców leczniczych w lecznictwie uzdrowiskowym, Nr ewid. 170/2018/P/18/098/LSZ, LSZ.430.003.2018, s. 11.

212 Rozporządzenie Ministra Zdrowia z dnia 13 III 2020 r. w sprawie ogłoszenia na obszarze Rzeczypospolitej Polskiej stanu zagrożenia epidemicznego (Dz.U. poz. 433) zob. $\S 5$ ust. 1 pkt 3 oraz $\S 10$ ust. 2 tego aktu. 
w zakresie lecznictwa uzdrowiskowego. Przy czym ograniczenia tego nie stosuje się w przypadku, gdy udzielanie świadczeń opieki zdrowotnej danemu pacjentowi rozpoczęło się przed dniem 14 marca 2020 r. Oznacza to, że pacjenci, którzy zostali skierowani na leczenie uzdrowiskowe lub rehabilitację, odbędą swój pobyt w uzdrowisku w terminie późniejszym. Konsekwencją tego mogą być zwiększone kolejki oczekujących. Będzie to znajdywać odzwierciedlenie również w zmniejszeniu wpływów do budżetu gmin uzdrowiskowych z tytułu pobieranej opłaty uzdrowiskowej w uzdrowisku i w redukcji atrakcyjności tego obszaru.

Jeżeli chodzi o możliwe sposoby ochrony praw pacjenta w kontekście korzystania ze świadczeń opieki zdrowotnej z zakresu lecznictwa uzdrowiskowego, to służy temu tryb skargowy. Jak wynika z najnowszego sprawozdania Rzecznika Praw Pacjenta ${ }^{213}$, w 2018 r. łącznie do oddziałów wojewódzkich NFZ wpłynęło 3915 skarg, które dotyczyły głównie realizacji umów o udzielanie świadczeń opieki zdrowotnej przez świadczeniodawców i działalności oddziałów, przede wszystkim zaniedbań lub nienależytego wykonywania zadań przez pracowników. $W$ ramach leczenia uzdrowiskowego odnotowano 121 skarg. Stosownie zaś do informacji podanych do wiadomości publicznej wśród wszystkich skarg rozpatrzonych w 2018 r. w NFZ ${ }^{214}$ - dotyczących lecznictwa uzdrowiskowego - jako zasadne uznano skargi odnoszące się m.in. do: (1) sposobu rozpatrzenia i kwalifikacji skierowania na leczenie uzdrowiskowe: (a) niezasadna odmowa potwierdzenia skierowania na leczenie uzdrowiskowe, (b) odesłanie skierowania do weryfikacji na niewłaściwy adres świadczeniodawcy, (c) nieterminowe potwierdzenia skierowania na leczenie uzdrowiskowe; (2) nieuzasadnionej dyskwalifikacji pacjenta z leczenia uzdrowiskowego; (3) wprowadzenia pacjenta w błąd przy przekazywaniu informacji dotyczącej terminu odesłania dokumentacji w związku z rezygnacją z leczenia uzdrowiskowego; (4) zachowania pracownika Działu Lecznictwa Uzdrowiskowego, Działu Współpracy Międzynarodowej, Wydziału Spraw Świadczeniobiorców (sala obsługi Interesariuszy), Działu ds. Wyrobów Medycznych; (5) zastrzeżeń do pracy delegatury $\mathrm{w}$ zakresie możliwości uzyskania informacji drogą telefoniczną; (6) przewlekłego postępowania dotyczącego zwrotu kosztów leczenia poza granicami kraju.

${ }^{213}$ Sprawozdanie dotyczace przestrzegania praw pacjenta na terytorium Rzeczypospolitej Polskiej. Obejmuje okres od 1 I do 31 XII 2018 r., s. 45.

${ }^{214}$ Zob. https://www.nfz.gov.pl/o-nfz/skargi-i-wnioski/ (dostęp: 10 III 2020). 


\section{Podsumowanie}

Pacjenci stanowią szczególną kategorię osób. Konstytucja RP i ustawodawstwo zwykłe co do zasady zapewniają prawo i równy dostęp do świadczeń z zakresu lecznictwa uzdrowiskowego będącego integralną częścią systemu ochrony zdrowia. Specyfika leczenia uzdrowiskowego opartego na wykorzystaniu naturalnych surowców leczniczych i klimatu sprawia, że działalność ta może być prowadzona tylko w gminie uzdrowiskowej na obszarze uzdrowiska i w specjalnie do tego przystosowanych zakładach lecznictwa uzdrowiskowego.

Świadczenia zdrowotne w zakładach lecznictwa uzdrowiskowego udzielane są na podstawie skierowania na leczenie uzdrowiskowe bądź rehabilitację uzdrowiskową lub zaświadczenia o braku przeciwwskazań do korzystania $\mathrm{z}$ danego rodzaju świadczeń zdrowotnych w danym uzdrowisku. Jeśli chodzi o podstawę przyjęcia do tych zakładów, nie ma znaczenia, czy dany pacjent przebywa w nich na podstawie skierowania NFZ czy za pełną odpłatnością (pobyty komercyjne). Ważne jest jedynie to, że przebywa w określonym typie zakładu w uzdrowisku i że ten pobyt jest świadczeniem zdrowotnym.

Przeprowadzone badania dowodza, że to, co potencjalnie powinno być dostępne dla zainteresowanych, czyli pacjentów korzystających ze świadczeń zdrowotnych z zakresu lecznictwa uzdrowiskowego, jest utrudnione m.in. przez bariery w postaci nadmiaru biurokracji, podporządkowania NFZ, złożonego modelu ubezpieczenia zdrowotnego. Ograniczenia, a w ślad za tym nierówny dostęp nierzadko wynikają także z samej procedury kierowania pacjenta na to leczenie. Dotyczy to zwłaszcza osób niesamodzielnych ze względu np. na niepełnosprawność czy zaawansowany wiek (seniorów). Inne mankamenty to kolejki oczekujących, brak wyboru przez pacjenta miejsca i czasu leczenia, stosowanie zamienników naturalnych surowców leczniczych czy ograniczenie dostępu do zakładu lecznictwa uzdrowiskowego poprzez wystąpienie w kraju zagrożenia epidemicznego.

Wydaje się, że aby stworzyć rzeczywiste gwarancje wynikające z prawa do świadczeń zdrowotnych, należałoby najpierw ukierunkować działania państwa na przemiany strukturalne w samym lecznictwie uzdrowiskowym, żeby mogło ono pełnić swoją podstawową rolę jako część systemu opieki zdrowotnej. Chodzi tu o dofinansowanie tego leczenia i przez to świadczenie usług zdrowotnych na wysokim poziomie, o odpowiedniej jakości. 


\section{THE PATIENT'S RIGHT TO HEALTH SERVICES IN THE FIELD OF SPA TREATMENT}

\section{S u m mary}

The right to use health services, including spa treatment, is one of the basic patient rights. The specificity of the issues undertaken stems from at least two sources. First of all, patients are a special category of people, because human health, as the highest value possessed by every human being, is subject to legal protection and requires their rights and freedoms are guaranteed. Secondly, spa treatment, which is an integral part of the health care system, corresponds to art. 68 of the Polish Constitution, assuming the fundamental principle according to which every citizen has the right to health care. On the other hand, this treatment means providing health services, which are conducted only in a separate area of the spa commune - a spa and in specially adapted medical entities - spa treatment centers.

The study covers the concise genesis of patient rights and the notion of the patient in terms of doctrine and legislation. Moreover, it contains the basic concepts related to spas. Recognition of the health needs of society is associated with a presentation of the individual types of spa treatment centers and spa treatment facilities, as well as the necessary conditions that they should meet. Due to the existing different status of patients in spa treatment institutions, the analysis covers the basis for admission, for referring and qualifying patients to these centers, and also the rules for using services guaranteed in the field of spa treatment. The patient's right to health services is also examined in the context of using these services. Despite the fact that patients' interest in this form of treatment increases every year, as is shown by the available data, there are a number of legal and organizational problems related to access to treatment as part of spa services.

Keywords: patient and patient's rights - health protection - health service - spa treatment - spa treatment center in a health resort

\section{LITERATURA}

Boratyńska M., Konieczniak P., Prawa pacjenta, Warszawa 2001.

Bujny J., Prawa pacjenta. Między autonomia a paternalizmem, Warszawa 2007.

Bukowska J., Prawne formy działania administracji, w: Nauka administracji, pod red. Z. Cieślaka, Warszawa 2017.

Celińska-Grzegorczyk K., Glosa do uchwaty z dnia 16 grudnia 2013 r., II GPS/13, „Zeszyty Naukowe Sądownictwa Administracyjnego" 2014, nr 5.

Chorąży K., Kmiecik Z., Wydawanie zaświadczeń - kwestie nie rozstrzygnięte w literaturze, "Samorząd Terytorialny" 2000, nr 6.

Chorąży K., Kmiecik Z., Zaświadczenia według kodeksu postępowania administracyjnego a inne akty potwierdzające, w: Administracja publiczna u progu XXI wieku. Prace dedykowane prof. zw. dr. hab. Janowi Szreniawskiemu z okazji Jubileuszu 45-lecia pracy naukowej, Przemyśl 2000. 
Cienkowski M., Wołowiec T., Opłata miejscowa i uzdrowiskowa jako daniny pobierane w miejscowościach turystycznych i uzdrowiskowych, "Zeszyty Naukowe Uczelni Warszawskiej im. Marii Skłodowskiej-Curie" 2014, nr 4(45).

Dercz M., Izdebski H., Organizacja ochrony zdrowia Rzeczypospolitej Polskiej w świetle obowiazujacego ustawodawstwa, Warszawa-Poznań 2001.

Dercz M., Izdebski H., Rek T., Prawo publiczne ochrony zdrowia, pod red. M. Dercza, Warszawa 2013.

Dercz M., Rek T., Prawa dziecka jako pacjenta, Warszawa 2003.

Dercz M., Rek T., Ustawa o działalności leczniczej. Komentarz, Warszawa 2011.

Dercz M., Rek T., Ustawa o działalności leczniczej. Komentarz, Warszawa 2014.

Dercz M., Rek T., Ustawa o zakładach opieki zdrowotnej. Komentarz, Warszawa 2007.

Fiałkiewicz, M. Starzewska, Uzdrowiska dolnoślaskie i ich okolice, Wrocław 1975.

Fijałek J., Indulski J., Opieka zdrowotna w Łodzi do roku 1845. Studium organizacyjno-prawne, Łódź 1990.

Halik J., Możliwości instytucjonalnej ochrony praw pacjenta w Polsce, w: Prawo do opieki zdrowotnej w systemie gospodarki rynkowej, pod red. M. Safjana, Warszawa 1993.

Halik J., Społeczeństwo polskie wobec opłat za niektóre świadczenia służby zdrowia, „Antidotum"1992, nr 4.

Hołub G., Pacjent jako osoba, w: Bioetyka w zawodzie lekarza, pod red. W. Chańskiej, J. Hartmana, Warszawa 2010.

Indulski J., Dawydzik L., Powszechne ubezpieczenie zdrowotne - ograniczenia i problemy, "Zdrowie Publiczne" 1997, nr 12.

Iwiński, Zmiany w leczeniu w uzdrowiskach, "Gazeta dla Pacjenta”. Dwumiesięcznik Porozumienia Pracodawców Ochrony Zdrowia, Rok IX, 2019, nr 2.

Jakimowicz W., Publiczne prawa podmiotowe, Kraków 2002.

Jankowska P., Szczególny charakter gmin uzdrowiskowych, w: Prawo i Administracja, t. 9, pod red. K. Wojtczak, Piła 2010.

Jończyk J., Prawo zabezpieczenia społecznego, Kraków 2006.

Jończyk J., Strony i stosunki powszechne ubezpieczenia zdrowotnego, "Prawo i Medycyna” 2005, nr 1.

Karkowska D., Prawa Pacjenta, Warszawa 2004.

Karkowska D., Prawa pacjenta, Warszawa 2009.

Karkowska D., Ustawa o prawach pacjenta i Rzeczniku Praw Pacjenta. Komentarz, Warszawa 2012.

Kempińska-Mirosławska B., Przekształcenia systemowe. Transformacja systemu ochrony zdrowia w Polsce, Warszawa 1998.

Kędziora R., Ogólne postępowanie administracyjne, Warszawa 2008.

Kopaliński W., Słownik wyrazów obcych i zwrotów obcojęzycznych z almanachem, Warszawa 1999.

Kruczek Z., Weseli A., Uzdrowiska karpackie, Kraków 1987.

Kulesza E., Uwagi do projektu ustawy o zasadach świadczeń gwarantowanych przez państwo ze środków publicznych, "Antidotum” 1994, nr 11.

Lach D.E., Zasada równego dostępu do świadczeń opieki zdrowotnej, Warszawa 2011.

Lenio P., Publicznoprawne źródła finansowania ochrony zdrowia, Warszawa 2018.

Leoński Z., Komentarz do art. 1-19, w: Z. Leoński, K. Wojtczak, Komentarz do ustawy o zakładach opieki zdrowotnej, Warszawa-Poznań 1993. 
Leoński Z., Zarys prawa administracyjnego, Warszawa 2000.

Machulak G., Komentarz do ustawy o świadczeniach opieki zdrowotnej finansowanych ze środków publicznych, Warszawa 2010.

Maśkiewicz M., Spojrzenie na budżet ochrony zdrowia, "Zdrowie Publiczne" 1993, nr 8.

Michalska-Badziak R., Ochrona zdrowia. Zagadnienia ogólne, w: Prawo administracyjne materialne, pod red. Z. Duniewskiej, B. Jaworskiej-Dębskiej, M. Stahl, Warszawa 2014.

Nesterowicz M., Prawo medyczne, Toruń 2000.

Nesterowicz M., Prawo medyczne, Torun 2007.

Nesterowicz M., Wyrok Sądu Najwyższego z dnia 1 grudnia 1998 r., III CKN 741/98, OSN 6/1999, poz. 112. Glosa, „Prawo i Medycyna” 2000, nr 6-7.

Nosko J., Promocja zdrowia i ochrona zdrowia jako zadania własne samorzadu terytorialnego, cz. 1, "Zdrowie Publiczne” 2000, nr 4.

Nosko J., Promocja zdrowia i ochrona zdrowia jako zadania własne samorzadu terytorialnego, cz. 2, "Zdrowie Publiczne" 2000, nr 5.

Nowak-Kubiak J., Łukasik B., Ustawa o świadczeniach opieki zdrowotnej finansowanych ze środków publicznych. Komentarz, Warszawa 2010.

Orzechowski K., Uwagi w sprawie ubezpieczeniowego charakteru ubezpieczenia zdrowotnego, w: Finansowanie ochrony zdrowia po reformie - ujęcie regionalne, pod red. M. Węgrzyn, Wrocław 2003.

Paszkowska M., Uzdrowiska w systemie ochrony zdrowia, Warszawa 2017.

Pietraszewska-Macheta, Komentarz do art. 15, w: Ustawa o świadczeniach opieki zdrowotnej finansowanych ze środków publicznych. Komentarz, pod red. A. Pietraszewskiej-Machety, Warszawa 2016, LEX/el.

Piotrowski J., Zabezpieczenie społeczne, Warszawa 1966.

Ponczek D., Prawa pacjenta w Polsce, Łódź 1999.

Promotion of the Rights of patients in Europe, Kluwer Law International 1995.

Sanetra W., Stosunki z zakresu ubezpieczenia zdrowotnego - jedność w różnorodności, „Przegląd Ubezpieczeń Społecznych i Gospodarczych” 2001, nr 3.

Słownik jezyka polskiego, t. 1 Warszawa 1978.

Słownik jezzyka polskiego, t. 2, Warszawa 1979.

Sygit M., Zdrowie publiczne, Warszawa 2010.

Tyczka S., Ponikowska I., Człowiek, pogoda, klimat, Warszawa 1978.

Ustawa o zawodach lekarza i lekarza dentysty. Komentarz, pod red. E. Zielińskiej, Warszawa 2008.

Węcłowicz-Bilska E., Uzdrowiska polskie. Zagadnienia programowo-przestrzenne, Kraków 2008.

Włodarczyk C., Reforma opieki zdrowotnej w Polsce. Studium polityki zdrowotnej, Kraków 1998.

Wojtczak A., Zdrowie publiczne wyzwaniem dla systemów zdrowia XXI wieku, Warszawa 2009.

Wojtczak K., Administracyjnoprawna reglamentacja wolnych zawodów, w: Rola materialnego prawa administracyjnego a ochrona praw jednostki, pod red. Z. Leońskiego, Poznań 1998.

Wojtczak K., Komentarz do art. 20-26, w: Z. Leoński, K. Wojtczak, Komentarz do ustawy o zakładach opieki zdrowotnej, Warszawa-Poznań 1993. 
Wojtczak K., Kompetencje i zadania jednostek samorzadu terytorialnego w zakresie bezpieczeństwa zdrowia ludzi, „Studia Prawa Publicznego” 2018, nr 3(23).

Wojtczak K., Rozważania nad pojęciem pacjenta, w: Jednostka w demokratycznym państwie prawa, pod red. J. Filipka, Bielsko-Biała 2003.

Wołowiec T., Pobyt w szpitalu uzdrowiskowym a obowiazek poboru opłaty uzdrowiskowej, „Przegląd Prawa Publicznego" 2016, nr 1.

Zimna T., Zawieranie umów o udzielanie świadczeń opieki zdrowotnej, Warszawa 2007. 